\title{
Greenhouse Evaluation of Seed and Drench Treatments for Organic Management of Soilborne Pathogens of Spinach
}

Jaime A. Cummings, MS Graduate, Department of Plant Pathology, Washington State University; Carol A. Miles, Associate Professor, and Lindsey J. du Toit, Associate Professor, Washington State University Mount Vernon Northwestern Washington Research and Extension Center, 16650 State Route 536, Mount Vernon, WA 98273

\begin{abstract}
Cummings, J. A., Miles, C. A., and du Toit, L. J. 2009. Greenhouse evaluation of seed and drench treatments for organic management of soilborne pathogens of spinach. Plant Dis. 93:1281-1292.

The efficacy of 14 seed and drench treatments for control of soilborne damping-off pathogens in organic production of spinach was evaluated in a greenhouse study. The efficacy of each treatment was compared with nontreated seed and seed treated with a conventional fungicide for control of Fusarium oxysporum f. sp. spinaciae, Pythium ultimum, and Rhizoctonia solani. Two experimental seed treatments, GTG I and GTG II (each comprised of a proprietary organic disinfectant and the latter also containing Trichoderma harzianum T22), provided equivalent control to the conventional fungicide, mefenoxam, against $P$. ultimum in one trial and significant reduction of damping-off in the second trial. Natural II and Natural X (Streptomycete products), and Subtilex (Bacillus subtilis) seed treatments each suppressed damping-off significantly in one of the two trials. For $R$. solani, GTG I and Natural II seed treatments reduced damping-off as effectively as a drench with the fungicide Terraclor (pentachloronitrobenzene). A soil drench with Prestop (Gliocladium catenulatum) suppressed postemergence wilt caused by $F$. oxysporum in both trials; a compost tea drench and seed treatment with Yield Shield (Bacillus pumilis) each suppressed postemergence wilt in only one of two trials. GTG I and GTG II significantly increased seed germination compared to nontreated seed. No treatment was effective against all three pathogens, and some treatments exacerbated damping-off.
\end{abstract}

In 1990, the U.S. Congress passed the Organic Foods Production Act (OFPA) as part of the U.S. Farm Bill in an effort to establish consistent organic production standards nationwide by implementing federally mandated organic standards. Disease management in organic production systems can be particularly challenging because organic producers do not have the option to utilize all of the conventional agricultural disease management tools. Thus, organic producers rely on methods of disease management such as crop rotation, cover cropping, and approved organic pesticides, including formulations of biological control organisms approved for organic production standards (24).

The demand for organically produced seed has increased since the rules of the United States Department of Agriculture (USDA) National Organic Program (NOP) have required the use of organic seed in organic production if organic seed is available that meets the desired characteristics of a grower's markets (14). Concern over

Corresponding author: L. J. du Toit

E-mail: dutoit@wsu.edu

Accepted for publication 22 July 2009.

doi:10.1094/PDIS-93-12-1281

(C) 2009 The American Phytopathological Society losses due to seedborne and soilborne pathogens has also increased because of the limited effective options available for seed treatments that satisfy organic standards (14). Seed treatments can be inexpensive and an effective means of plant disease management (42). Biological control agents that reduced damping-off caused by Pythium spp. on a variety of crops include, for example, Enterobacter cloaceae, Pantoea agglomerans, Pseudomonas fluorescens, Rhizobium leguminosarum bv. viceae, Trichoderma spp., and compost teas $(20,21,33,37,43)$. Similarly, Pseudomonas aeruginosa, P. fluorescens, Pseudomonas putida, Trichoderma harzianum, Gliocladium spp., and Bacillus amyloliquefaciens reduced damping-off caused by Rhizoctonia spp. on various crops $(4,7,15$, 17,28,29,39); and Burkholderia cepacia, E. cloaceae, nonpathogenic Fusarium spp., Gliocladium virens, Glomus intraradices, Glomus mosseae, P. fluorescens, P. putida, Rhizobium leguminosarum, and Trichoderma spp. reduced wilts caused by Fusarium spp. (2,12,13,26,27,36). Although many commercial biological seed and drench treatments have been developed to protect seed and seedlings against soilborne plant pathogens, there is a need for seed treatments approved for use in organic production that are effective against a diversity of soilborne pathogens. Various products have been developed for organic production for which the registrants claim efficacy against particular soilborne pathogens, although results of independent studies in which these claims have been evaluated sometimes have been highly variable (16).

The purpose of this research was to provide an objective evaluation of seed and drench treatment products that have received U.S. Environmental Protection Agency (EPA) registration for use in organic production in the United States, as well as products that have the potential for approved use in organic production, for control of soilborne seedling blight or damping-off diseases of vegetables. Three pathogens were selected for evaluating these treatments on the basis of individual and collective impacts on seedling blight and damping-off complexes of many small-seeded vegetables: Rhizoctonia solani Kühn, which causes seed rot and damping-off (40); Fusarium oxysporum f. sp. spinaciae (Sherb.) Snyd. \& Hans., the cause of seedling blight and vascular wilt of spinach (5); and Pythium ultimum Trow, the cause of pre- and postemergence damping-off of seedlings (18). Spinach (Spinacia oleracea) is susceptible to many prevalent soilborne pathogens that cause seedling blights and damping-off, and is a common crop for organic leafy vegetable markets (8). Therefore, spinach was used in this study as a model small-seeded vegetable crop for investigating efficacy of the selected seed and drench treatments for control of soilborne pathogens in organic production systems. The specific objectives were to evaluate seed and drench treatments on spinach in a greenhouse against each pathogen, determine if any of the seed treatments affect the incidence of necrotrophic fungi on spinach seed, and determine if any of the seed treatments affect spinach seed germination.

\section{MATERIALS AND METHODS}

Pathogen isolates. The isolate of $P . u l$ timum used in this study, '030141', was originally obtained from wheat seedlings in the Palouse Region of Washington State by T. Paulitz (USDA ARS, Pullman, WA); its ability to cause disease on spinach seedlings was verified prior to this study (L. J. $\mathrm{du}$ Toit, unpublished). The isolate was preserved on potato dextrose agar (PDA) and water agar (WA) slants in test tubes, and stored at $4{ }^{\circ} \mathrm{C}$ with transfers to new slants every 6 months. 
The isolate of $R$. solani used in this study, VSP 05-01B, was originally obtained from an onion plant in Washington State in 2005 and verified as pathogenic on spinach (L. J. du Toit, unpublished). The isolate was identified as belonging to anastomosis group 4 (AG4) and hyphal group II (HGII) by C. Pagani at North Carolina State University (Raleigh), on the basis of morphological characterization, nuclear condition, anastomosis grouping, and DNA sequencing of the internal transcribed spacer (ITS) regions 1 and 2 and the 5.8S rDNA region (40). For long-term preservation of the isolate, $250 \mathrm{~g}$ of rye seed was soaked in 0.5 liter of deionized water for $24 \mathrm{~h}$, autoclaved at $120^{\circ} \mathrm{C}$ and $103 \mathrm{kPa}$ for $90 \mathrm{~min}$, cooled for $24 \mathrm{~h}$, and autoclaved a second time for $90 \mathrm{~min}$ at $120^{\circ} \mathrm{C}$ at 103 $\mathrm{kPa}$. Ten plugs (each $5 \mathrm{~mm}$ in diameter) were taken from the edge of actively growing colonies of the $R$. solani isolate on PDA, added to the rye seed, and incubated on a lab bench for 2 weeks for the fungus to colonize the rye seed. The flasks were shaken intermittently to promote colonization of the seed. The colonized seed was then dried for 1 week in a fume hood and stored in a refrigerator. Isolates of the pathogen were preserved by macerating the colonized rye seed using a coffee grinder, and storing the macerated tissue at $4^{\circ} \mathrm{C}$. The isolates were also stored on colonized filter disks at $-20^{\circ} \mathrm{C}$. For the latter, four $1.5 \mathrm{~cm}$ diameter sterile filter disks (VWR Scientific Products, West Chester, PA) were arranged on PDA in a $6 \mathrm{~cm}$ diameter petri dish, and a colonized plug (5 $\mathrm{mm}$ diameter) taken from the edge of an actively growing PDA culture of the isolate was placed in the middle of the filter disks. Once the filter disks were covered with mycelium of the fungus, the disks were removed, placed in sterile coin envelopes $(5.7 \times 8.9 \mathrm{~cm})$ (Westvaco Envelope Division, Springfield, MA), dried overnight in a laminar flow hood, and stored with desiccant at $-20^{\circ} \mathrm{C}(35)$.

Isolate '001' of $F$. oxysporum f. sp. spinaciae was obtained from a wilted spinach plant in a spinach seed crop trial at the Washington State University Mount Vernon Northwestern Washington Research and Extension Center (WSU Mount Vernon NWREC) in Mount Vernon in 2001 and was verified as pathogenic on spinach prior to this study (L. J. du Toit, unpublished). For long-term storage, a culture in $50 \mathrm{ml}$ of Kerr's broth (23) in a flask was placed on a shaker for 5 days for production of microconidia. Aliquots $(3 \mathrm{ml})$ of the microconidial suspension were dispensed into $20 \mathrm{ml}$ vials each containing $15 \mathrm{~g}$ sterile soil/sand mixture (1:1 ratio), and shaken vigorously to disperse spores in the soil. The vial was kept at room temperature (approximately $24^{\circ} \mathrm{C}$ ) for 2 days and then at $4^{\circ} \mathrm{C}$ for long-term preservation of the pathogen. The isolate was also stored on filter disks as described for $R$. solani.
Inoculum concentration trials. To optimize trials, inoculum concentration assays were carried out in a greenhouse for each pathogen to determine the concentration of inoculum that would achieve approximately $50 \%$ damping-off or wilt when nontreated seed was planted under the conditions of these trials. To produce inoculum for the assays, nonsterile Puget silt loam field soil (Klungland and McArthur, 1989) from the WSU Mount Vernon NWREC was sieved $(1 \mathrm{~mm}$ size mesh) and then air-dried for 2 days on a greenhouse bench. Ground oatmeal (Quaker, Chicago, IL) was added (1\% by weight) to the dried, sieved soil and mixed thoroughly in a PK Blendmaster soil blender (Paterson-Kelley Co. Division of Harsco Corp., East Stroudsburg, PA) for $10 \mathrm{~min}$. During the last $5 \mathrm{~min}$ of mixing, deionized water $(15 \% \mathrm{wt} / \mathrm{wt})$ was added to the soil/oatmeal mix in the blender. Next, $500 \mathrm{~g}$ of this mixture was added to a 0.95 liter glass jar. The jar was topped with an autoclavable plastic lid used for mushroom spawning (Fungi Perfecti, Olympia, WA), with a $1.27 \mathrm{~cm}$ diameter hole drilled into the lid and a $70 \mathrm{~mm}$ diameter synthetic filter disk (Fungi Perfecti) placed beneath the lid. The lid was covered with two layers of aluminum foil and the jar and contents autoclaved for $50 \mathrm{~min}$ at $120^{\circ} \mathrm{C}$ and $103 \mathrm{kPa}$. Each jar was then autoclaved again approximately $24 \mathrm{~h}$ later for $50 \mathrm{~min}$. The soil/oatmeal mixture was stored at room temperature until used to produce inoculum.

Three- to four-day-old cultures of $P . u l$ timum, $R$. solani, or $F$. oxysporum $\mathrm{f}$. sp. spinaciae grown on PDA were used to inoculate the soil/oatmeal mix individually. After five colonized agar plugs, each approximately $9 \mathrm{~mm}^{3}$, were placed in each jar, the jars were shaken manually. The jars were then placed on a lab bench at room temperature for 4 weeks until the soil/oatmeal mix was thoroughly colonized by the pathogen, and then stored at $4{ }^{\circ} \mathrm{C}$ until used in the greenhouse trials. The concentration of inoculum in the soil/oatmeal mix for each pathogen was quantified using soil-dilution plating. Each jar was shaken vigorously. A $10 \mathrm{~g}$ sample of inoculum was then added to a $200 \mathrm{ml}$ flask containing $90 \mathrm{ml}$ of $0.1 \%$ WA (sloppy agar) to suspend the inoculum, and the flask was placed on a rotating platform shaker for $12 \mathrm{~min}$. Tenfold dilutions of each suspension were carried out to $10^{-4}$ using sloppy agar. Dilutions of $F$. oxysporum f. sp. spinaciae inoculum were plated onto Komada's agar medium (25) and incubated at room temperature on a laboratory bench. F. oxysporum colonies were counted after 4 days to determine the number of CFU/g inoculum. The P. ultimum inoculum dilution series was plated similarly onto a Pythium-selective medium (PSM) (30). The plates were incubated in the dark at room temperature because rose
Bengal and rifampicin in the medium are light-sensitive. Colonies of $P$. ultimum were counted after 40 to $48 \mathrm{~h}$ to calculate $\mathrm{CFU} / \mathrm{g}$ inoculum. The $R$. solani inoculum dilution series was plated onto WA and incubated at room temperature on a lab bench. $R$. solani colonies were counted 24 $\mathrm{h}$ after plating to determine CFU/g inoculum.

Approximately $1,200 \mathrm{~g}$ of wetted Sunshine Growers Organic potting mix (Sun Gro Horticulture) was used in each $30.5 \times$ $30.5 \times 6.4 \mathrm{~cm}$ flat for inoculum concentration assays. Inoculum concentrations of 0 , $500,1,000,5,000$, and 10,000 CFU/g wetted potting mix were evaluated for damping-off or wilt caused by each of the three pathogens. However, the concentrations proved too low for $F$. oxysporum f. sp. spinaciae and $R$. solani (data not shown), so the trials were repeated for these two pathogens using $0,5,000,10,000,50,000$, and $100,000 \mathrm{CFU} / \mathrm{g}$, as well as 500,000 $\mathrm{CFU} / \mathrm{g}$ for $F$. oxysporum $\mathrm{f}$. sp. spinaciae. Similarly, the treatment of $50 \mathrm{CFU} / \mathrm{g}$ was not included in the second $P$. ultimum trial. Because of excessive wilt at 100,000 and $500,000 \mathrm{CFU} / \mathrm{g}$ in the first $F$. oxysporum $\mathrm{f}$. $\mathrm{sp}$. spinaciae trial, these concentrations were not included in the second trial. For each pathogen, the potting medium was mixed with the appropriate volume of soil/oatmeal inoculum for 5 min using a Gustafson Batch Lab Treater (Gustafson Equipment, Bayer CropScience, Shakopee, $\mathrm{MN})$. The inoculated potting mix was then portioned into flats $(1,200 \mathrm{~g} / \mathrm{flat})$. Thirtysix seeds of the spinach hybrid 'Lazio' (Pop Vriend Seeds BV, Andijk, the Netherlands) were planted per flat (six rows of six seeds planted at a $5 \mathrm{~cm}$ spacing within and between rows). Lazio was selected due to the popularity of this hybrid in the fresh market, susceptibility of the hybrid to damping-off pathogens, and resistance to 10 races of the spinach downy mildew pathogen (22). A separate trial was carried out for each pathogen in a greenhouse at approximately $25 \pm 5^{\circ} \mathrm{C}$ using a randomized complete block design with five replications of the five or six inoculum concentrations. Each trial was repeated once.

The incidence of seedling emergence and the incidence of postemergence damping-off or wilt were counted in each flat at 3- to 4-day intervals for 32 to 56 days, depending on how rapidly symptoms developed and progressed. In the repeated trial for each pathogen, ratings were completed every 7 days. Flats were fertilized weekly with an OMRI-listed organic fertilizer (Alaska Fish Fertilizer, 5:1:1, Lilly Miller Brands, Walnut Creek, CA) at 7.9 $\mathrm{ml} / \mathrm{liter}$ water. The OMRI-listed insecticides Entrust (spinosad, Dow AgroSciences, Indianapolis, IN) and AzaDirect (azadirachtin, Gowan Company, Yuma, AZ) were applied to the seedlings at 0.17 $\mathrm{g} /$ liter water and $1.6 \mathrm{ml} /$ liter water, respectively, as necessary for thrips and aphid 
management, respectively. Isolations were carried out in each trial on randomly selected seedlings to confirm the pathogen responsible for damping-off or wilt. For each trial, five symptomatic and three asymptomatic seedlings (including roots) were rinsed under running tap water and the foliage above the crown removed. The crown and roots were surface-sterilized in $0.6 \% \mathrm{NaOCl}$ for $60 \mathrm{~s}$, triple rinsed in sterile water, dried on sterile paper towel, cut into $5 \mathrm{~mm}$ long pieces, plated onto PDA and WA, and incubated on a lab bench for 3 to 5 days. Fungi and oomycetes that developed were identified microscopically to genus. In the repeated trial for each pathogen, all of the emerged seedlings in each flat were cut at the soil line at the final rating. The aboveground foliage was dried at $32^{\circ} \mathrm{C}$ (Model 1370F forced air oven, VWR Scientific Products, West Chester, PA) for 3 days.

Seed and drench treatment trials. On the basis of the inoculum concentration trials, the concentration of inoculum that resulted in approximately $50 \%$ mortality of spinach seedlings 5 to 7 weeks after planting was selected for evaluating seed and drench treatments: $1,000 \mathrm{CFU} / \mathrm{g}$ for $P$. ultimum, 10,000 CFU/g for $F$. oxysporum f. sp. spinaciae, and 50,000 CFU/g for $R$. solani. Excessive preemergence dampingoff was observed in the first $R$. solani trial, so the concentration was reduced to 25,000 $\mathrm{CFU} / \mathrm{g}$ for the second $R$. solani trial. Fourteen biological and/or organic seed or drench treatments and a conventional fungicide seed or drench treatment were evaluated in greenhouse assays against each of the three pathogens. Details of the treatments are shown in Table 1. The two control treatments included nontreated seed planted in inoculated potting mix and nontreated seed planted in noninoculated potting mix. Each trial was arranged as a randomized complete block design with five replications. For each experimental unit, six rows of six seed (cv. Lazio) were planted into a $30.5 \times 30.5 \times 6.4 \mathrm{~cm}$ tall flat with $5 \mathrm{~cm}$ within and between rows. Each trial for each pathogen was repeated.

Each treatment was applied at the highest rate recommended by the label or the manufacturer. GTG I, GTG II, Natural II, and Natural $X$ seed treatments were applied by the respective companies. All other products were applied at the WSU Mount Vernon NWREC. The compost tea, brewed by C. Crosby at the WSU Crop and Soil Sciences Department (Pullman, WA),

Table 1. Seed and drench treatments evaluated in greenhouse trials for efficacy against damping-off and vascular wilt of spinach caused by Pythium ultimum, Rhizoctonia solani, and Fusarium oxysporum f. sp. spinaciae ${ }^{\mathrm{u}}$

\begin{tabular}{|c|c|c|c|c|c|}
\hline Treatment $^{v}$ & $\begin{array}{l}\text { Active ingredient } \\
\text { (concentration in product) }\end{array}$ & $\begin{array}{l}\text { Registrant or } \\
\text { manufacturer }\end{array}$ & Method of application & $\begin{array}{l}\text { Rate of product } \\
\text { applicationw }^{\text {applich }}\end{array}$ & $\begin{array}{l}\text { OMRI- } \\
\text { listed }^{x}\end{array}$ \\
\hline Compost tea & $\begin{array}{l}\text { High bacterial diversity compost } \\
\text { tea }^{\mathrm{y}}\end{array}$ & $\begin{array}{l}\text { Washington State } \\
\text { University, Pullman }\end{array}$ & $\begin{array}{l}\text { Drench immediately after } \\
\text { planting }\end{array}$ & $\begin{array}{l}646 \text { liters } / 100 \mathrm{~m}^{3} \\
\text { potting mix }\end{array}$ & Yes \\
\hline GTG I & $\begin{array}{l}\text { Proprietary organic disinfectant } \\
\text { (unknown rate) }\end{array}$ & $\begin{array}{l}\text { Germain's Technology } \\
\text { Group, Gilroy, CA }\end{array}$ & Seed treatment & Proprietary & $\begin{array}{l}\text { Not yet } \\
\text { applied }\end{array}$ \\
\hline GTG II & $\begin{array}{l}\text { Proprietary organic disinfectant } \\
+ \text { Trichoderma harzianum T-22 } \\
\text { (unknown rates) }\end{array}$ & $\begin{array}{l}\text { Germain's Technology } \\
\text { Group }\end{array}$ & Seed treatment & Proprietary & $\begin{array}{l}\text { Not yet } \\
\text { applied }\end{array}$ \\
\hline $\begin{array}{l}\text { Kodiak Concentrate } \\
\text { Biological Fungicide }\end{array}$ & Bacillus subtilis $(1.37 \%)$ & $\begin{array}{l}\text { Bayer CropScience, } \\
\text { Research Triangle Park, NC }\end{array}$ & Slurry seed treatment & $31.2 \mathrm{~g} / 100 \mathrm{~kg}$ seed & Yes \\
\hline $\begin{array}{l}\text { Micro } 108 \text { Seed Inoculant } \\
+ \text { Actinovate AG }\end{array}$ & $\begin{array}{l}\text { Streptomyces lydicus }\left(10^{8} \mathrm{CFU} / \mathrm{g}\right) \\
+ \text { S. lydicus }\left(10^{7} \mathrm{CFU} / \mathrm{g}\right)\end{array}$ & $\begin{array}{l}\text { Natural Industries, } \\
\text { Houston, TX }\end{array}$ & $\begin{array}{l}\text { Dry seed coating }+ \text { drench } \\
\text { immediately after planting }\end{array}$ & $\begin{array}{l}1.76 \mathrm{~kg} / 100 \mathrm{~kg} \text { seed }+ \\
1.29 \mathrm{~kg} / 100 \text { liters water }\end{array}$ & Yes \\
\hline $\begin{array}{l}\text { Mycostop Mix } \\
\text { Biofungicide }\end{array}$ & Streptomyces griseoviridis (4\%) & $\begin{array}{l}\text { Verdera Oy, Luoteisrinne, } \\
\text { Finland }\end{array}$ & Dry seed coating & $625.7 \mathrm{~g} / 100 \mathrm{~kg}$ seed & Yes \\
\hline Natural II & Actinomycete $(0.6 \%)$ & Agricoat LLC, Soledad, CA & Seed treatment & $750.7 \mathrm{~g} / 100 \mathrm{~kg}$ seed & No \\
\hline Natural X & Actinomycete $(0.6 \%)$ & Agricoat LLC & Seed treatment & $750.7 \mathrm{~g} / 100 \mathrm{~kg}$ seed & No \\
\hline PGPR Galaxy & Bacterial mixture $^{z}$ & $\begin{array}{l}\text { Holmes ENVIRO, LLC, } \\
\text { Philomath, OR }\end{array}$ & Slurry seed treatment & $223 \mathrm{ml} / 100 \mathrm{~kg}$ seed & Yes \\
\hline $\begin{array}{l}\text { Prestop Biofungicide } \\
\text { Powder }\end{array}$ & Gliocladium catenulatum (32\%) & Verdera Oy & $\begin{array}{l}\text { Drench immediately after } \\
\text { planting }\end{array}$ & $180 \mathrm{~g} / 100$ liters water & No \\
\hline $\begin{array}{l}\text { SoilGard } 12 \mathrm{G} \\
\text { Microbial Fungicide }\end{array}$ & Gliocladium virens (12\%) & Certis USA, Columbia, MD & $\begin{array}{l}\text { Drench }>24 \mathrm{~h} \text { before } \\
\text { planting }\end{array}$ & $239.7 \mathrm{~g} / 100$ liters water & Yes \\
\hline $\begin{array}{l}\text { Subtilex Biological } \\
\text { Fungicide }\end{array}$ & Bacillus subtilis (2.75\%) & $\begin{array}{l}\text { Becker Underwood, Ames, } \\
\text { IA }\end{array}$ & Slurry seed treatment & $15.6 \mathrm{~g} / 100 \mathrm{~kg}$ seed & No \\
\hline $\begin{array}{l}\text { T-22 Planter Box } \\
\text { Biological Fungicide }\end{array}$ & $\begin{array}{l}\text { Trichoderma harzianum T-22 } \\
(1.15 \%)\end{array}$ & BioWorks, Victor, NY & $\begin{array}{l}\text { Dry seed coating }+ \text { drench } \\
4 \text { days after planting }\end{array}$ & $250 \mathrm{~g} / 100 \mathrm{~kg}$ seed & Yes \\
\hline $\begin{array}{l}\text { Yield Shield } \\
\text { Concentrate Biological } \\
\text { Fungicide }\end{array}$ & Bacillus pumilis $(0.28 \%)$ & Bayer CropScience & Slurry seed treatment & $6.26 \mathrm{~g} / 100 \mathrm{~kg}$ seed & Yes \\
\hline Apron XL LS & Mefenoxam (33\%) & $\begin{array}{l}\text { Syngenta Crop Protection, } \\
\text { Greensboro, NC }\end{array}$ & Slurry seed treatment & $20.8 \mathrm{ml} / 100 \mathrm{~kg}$ seed & No \\
\hline Mertect 340F & Thiabendazole $(42.3 \%)$ & Syngenta Crop Protection & Slurry seed treatment & $122.4 \mathrm{ml} / 100 \mathrm{~kg}$ seed & No \\
\hline Terraclor $75 \% \mathrm{WP}$ & Pentachloronitrobenzene (75\%) & $\begin{array}{l}\text { Crompton Uniroyal } \\
\text { Chemical, Middlebury, CT }\end{array}$ & $\begin{array}{l}\text { Drench immediately after } \\
\text { planting }\end{array}$ & $59.9 \mathrm{~g} / 100$ liters water & No \\
\hline Nontreated seed & - & - & - & - & - \\
\hline
\end{tabular}

u Each trial was a randomized complete block design with four or five replications. Potting mix was inoculated with the selected pathogen at a concentration determined by inoculum concentration trials, and planted with the spinach hybrid Lazio.

v Products were evaluated separately against each pathogen. Some products were not approved by the USDA National Organic Program (NOP) or the Organic Materials Review Institute (OMRI) for use in organic systems in 2007 (see OMRI website for a list of approved products). Micro 108 Seed Inoculant + Actinovate AG, Mycostop Mix Biofungicide, T-22 Planter Box Biological Fungicide, and Apron XL LS were approved by the Washington State Department of Agriculture for use on certified organic spinach crops in Washington in 2007 when this study was completed. Apron XL LS, Mertect 340F, and Terraclor 75\% WP were conventional treatments for Pythium spp., Fusarium spp., and Rhizoctonia spp., respectively. Nontreated seed was also a control treatment.

${ }^{w}$ Each product was evaluated at the highest recommended label rate for spinach and/or a crop with similar size seed or according to registrant recommendations. Drenches were applied according to the label based on surface area or volume of potting medium treated.

x Not yet applied = registrant had not applied for OMRI approval by March 2007.

y Ingredients of the compost tea: vermicompost ( $50 \mathrm{ml} / \mathrm{liter})$, seaweed powder ( $1 \mathrm{ml} / \mathrm{liter})$, liquid humic acids ( $2 \mathrm{ml} / \mathrm{liter})$, and Azomite rock dust ( $3 \mathrm{~g} / \mathrm{liter})$ (37). The compost tea was brewed by C. Crosby at Washington State University, Pullman, where the tea was aerated for $24 \mathrm{~h}$ prior to shipment to the WSU Mount Vernon NWREC, where the tea was applied at 0.6 liter/1,200 g potting mix/flat.

z PGPR Galaxy contains Bacillus azotofixans, Azotobacter chroococcum, Pseudomonas putida, and Pseudomonas fluorescens (each at $304 \times 10^{9}$ cells/liter). 
was developed for high bacterial diversity, and was brewed with vermicompost, seaweed powder, liquid humic acids, and azomite rock dust as described by Scheuerell and Mahaffee (37). The compost tea was brewed the day prior to planting each trial and shipped overnight to the WSU Mount Vernon NWREC.

The number of emerged seedlings and the number of damped-off or wilted seedlings were counted weekly for 4 to 7 weeks, depending on the pathogen. $P$. $u l$ timum and $R$. solani each caused significant preemergence damping-off, followed by postemergence damping-off within 3 weeks of emergence. Therefore, trials with $P$. ultimum and $R$. solani were terminated 4 to 5 weeks after planting. Trials with $F$. oxysporum f. sp. spinaciae were continued up to 7 weeks since this pathogen primarily caused postemergence wilt 4 to 7 weeks after planting. Trials with $P$. ultimum and $R$. solani were completed at $25 \pm$ $5^{\circ} \mathrm{C}$, whereas the $F$. oxysporum f. sp. spinaciae trials were carried out at $28 \pm$ $3^{\circ} \mathrm{C}$ to enhance expression of vascular wilt as a result of increased transpirational demand of seedlings at higher temperatures.

The plants in each trial were fertilized weekly with the OMRI-listed organic fish fertilizer as described for the inoculum concentration trials, but mixed with a seaweed extract fertilizer (Acadian Seaplants Limited, Dartmouth, Nova Scotia, Canada) applied at $2.5 \mathrm{~g} /$ liter water. The seedlings in each flat were cut at the soil line at the final rating to determine total dry foliar biomass/flat. Isolations onto PDA and WA were completed from five symptomatic and three asymptomatic seedlings randomly selected from each trial, as described for the inoculum concentration trials.

Because the $\mathrm{pH}$ of the potting medium may impact biological control organisms (16), and aggressiveness of plant pathogens may be affected by $\mathrm{pH}(10)$, the $\mathrm{pH}$ of the potting mix in a subset of the trials was measured after the mix was moistened and immediately before planting. For each $\mathrm{pH}$ assessment, three $10 \mathrm{~g}$ samples of potting mix were sampled randomly from the flats. Each sample was added to $30 \mathrm{ml}$ deionized water, stirred for $30 \mathrm{~s}$, left standing for $10 \mathrm{~min}$, and the process repeated twice before the $\mathrm{pH}$ was measured using a Symphony pH meter (VWR).

Health assay of treated seeds. A modified freeze-blotter seed health assay was carried out for each of the seed treatments to determine the incidence of seed infected with various necrotrophic fungi, as described by du Toit et al. (11) with slight modifications. All seed treatments were assessed in the seed health assays, including two conventional seed treatments (Apron XL LS and Mertect 340F) and nontreated seed. Four replications of 100 seeds were assayed per treatment. The seeds were arranged on sterile Steel blue germination blotters $(8.25 \mathrm{~cm}$ diameter, Anchor Paper Co., St. Paul, MN) moistened with $5 \mathrm{ml}$ sterile water in $10 \mathrm{~cm}$ diameter plastic petri plates (20 seeds per plate). After the plates were sealed with Parafilm, the seeds were left to imbibe for $25 \mathrm{~h}$. The plates were then moved to a $-20^{\circ} \mathrm{C}$ freezer for $25 \mathrm{~h}$ to kill the embryos, thawed at room temperature for 15 to 30 min, and placed in an incubator (Model I30BLL, Percival Scientific, Perry, IA) maintained at $24^{\circ} \mathrm{C}$ for 14 days with a 12 $\mathrm{h} / 12$-h day/night cycle (near-UV and fluorescent white light by day). The seeds were examined microscopically $(\times 10$ to $\times 100$ magnification) 5, 9, and 14 days after plating. Necrotrophic fungi developing on the seed were identified based on morphological characteristics. The seed health assay was repeated using a different commercial seed lot of Lazio spinach that was also used in the second greenhouse seed and drench treatment trial for each pathogen, because there was insufficient seed of the first lot remaining after the first set of greenhouse trials.

Germination assay of treated seeds. For each of the two seed lots used in the seed and drench treatment trials, 100 seeds per treatment were subjected to a germination assay based on the protocol of the Association of Official Seed Analysts (44). Fifty seeds were placed between two layers of seed germination blotters $(25.4 \times$ $38.1 \mathrm{~cm}, 38 \#$ regular weight; Anchor Paper Co.) moistened with deionized water. For each replication of each treatment, each of two sets of blotters containing 50 seeds was rolled up in a sheet of waxed paper $(61 \times 91.4 \mathrm{~cm}$; Anchor Paper Co. $)$ and placed upright in a plastic bag in a seed germinator (Stults Scientific Engineering Corp., Springfield, IL) at $15^{\circ} \mathrm{C}$ with no light. The incidence (\%) of seed germinated after 7, 14, and 21 days was counted. At the final rating, the incidence of seeds with abnormal germination and the incidence of rotten seeds were counted. In addition, a 5 day reading was included in the second assay to determine if any treatments caused significantly earlier germination compared with nontreated seed.

Statistical analyses. Analyses of variance (ANOVAs) and means comparisons using Fisher's protected least significant difference (LSD at $P<0.05$ ) were carried out using PROC GLM of SAS (Version 9.1, SAS Institute, Cary, NC) for each of the dependent variables in the seed health assays, germination assays, inoculum concentration trials, and seed and drench treatment trials. Friedman's nonparametric rank test was used when the data and transformations (logarithmic, square root, or arcsine square root) did not meet assumptions for parametric analyses, i.e., normally distributed residuals with homogeneous variances (41). For each trial, the percentage of preemergence damping-off per flat was calculated by subtracting the percentage of nonemerged seedlings for the nontreated seed in noninoculated medium $[=36-$ (number of emerged seedlings)] from the percentage of nonemerged seedlings in that flat. Postemergence damping-off or wilt was calculated as a percentage of emerged seedlings. Total aboveground dry biomass per flat was determined as described above, as well as the area under emergence progress curve (AUEPC), area under preemergence disease progress curve $\left(\mathrm{AUDPC}_{\mathrm{pre}}\right)$, area under postemergence disease progress curve $\left(\mathrm{AUDPC}_{\text {post }}\right)$, and area under total disease progress curve $\left(\mathrm{AUDPC}_{\text {total }}\right)$. The area under emergence or disease progress curves is a cumulative measurement calculated as an average of emergence or disease ratings over time: $\left[\left(\Sigma\left(y_{i}+y_{i+1} / 2\right)\left(t_{i}-\right.\right.\right.$ $\left.t_{i+1}\right)$ ], in which $y_{i}=$ number of emerged or diseased seedlings at the $i$ th rating, $y_{i+1}=$ number of emerged or diseased seedlings at the $(i+1)$ rating, $t_{i}=$ number of days at the ith rating, and $t_{i+1}=$ number of days at the $(i+1)$ rating $(38)$. Data were analyzed separately for repeated trials because of different inoculum concentrations evaluated in the repeated inoculum concentration trials, and because of significant trial main effects and interaction terms in the combined ANOVAs.

\section{RESULTS}

Inoculum concentration trials. The soil/oatmeal inoculation method for $P$. ultimum, F. oxysporum f. sp. spinaciae, and $R$. solani produced damping-off or wilt of spinach seedlings (Fig. 1). Isolations from symptomatic seedlings confirmed the presence of the appropriate pathogen. The pathogens were not isolated from asymptomatic seedlings.

$P$. ultimum caused pre- and postemergence damping-off at similar incidences. In trial 1, emergence in noninoculated flats was $92.3 \pm 2.4 \%$ (mean \pm standard error) by 32 days after planting (dap) versus 60.8 to $68.3 \%$ at 500 to $5,000 \mathrm{CFU} / \mathrm{g}$, respectively (Fig. 1A) (not significantly different among these concentrations at $P<0.05$ ). Concentrations of 100 to $5,000 \mathrm{CFU} / \mathrm{g}$ resulted in 30 to $65 \%$ damping-off by 32 dap (Fig. 1A). However, total preemergence and postemergence damping-off at $500,1,000$, and 5,000 CFU/g were not significantly different (Fig. 1A). Total damping-off at $50 \mathrm{CFU} / \mathrm{g}$ was only $8.7 \pm$ $2.5 \%$. In trial 2 , emergence in noninoculated flats by 35 dap averaged $91.7 \pm 2.5 \%$, and ranged from 56.1 to $65.0 \%$ in inoculated flats (Fig. 1B). The incidence of damping-off did not differ significantly at 100 to $5,000 \mathrm{CFU} / \mathrm{g}$ by 35 dap (50.8 to $74.2 \%$; Fig. 1B). Total, preemergence, and postemergence damping-off did not differ significantly at 500 to 5,000 CFU/g (Fig. 1B). Biomass of noninoculated seedlings was $2.37 \pm 0.2 \mathrm{~g}$ and declined with increasing inoculum concentration (1.12 \pm 
0.1 and $0.65 \pm 0.1 \mathrm{~g}$ at 100 and $500 \mathrm{CFU} / \mathrm{g}$, respectively), but was not significantly different from 500 to $5,000 \mathrm{CFU} / \mathrm{g}(0.62 \pm 0.1$ and $0.46 \pm 0.1 \mathrm{~g}$ at 1,000 , and 5,000 CFU/g, respectively) (data not shown).

Preemergence damping-off caused by $R$. solani occurred at a greater incidence than postemergence damping-off at the highest inoculum concentrations (Fig. 1C and D, respectively). Inoculum concentration significantly $(P<0.05)$ affected emergence as well as preemergence, postemergence, and total damping-off weekly in both trials, except postemergence wilt 7 dap (data not shown). In trial 1 , emergence in noninoculated flats reached $80.6 \% 32$ dap versus 85.6, 70.6, 57.8, and $12.8 \%$ at $5,000, \quad 10,000, \quad 50,000$, and 100,000 $\mathrm{CFU} / \mathrm{g}$, respectively. Similarly, preemergence and postemergence damping-off was greatest at 100,000 CFU/g (67.8 and $34.0 \%$, respectively). Total damping-off 32 dap ranged from 7.0 to $88.0 \%$ at 5,000 to $100,000 \mathrm{CFU} / \mathrm{g}$ (Fig. 1C), with no signifi- cant difference at 5,000 $\mathrm{CFU} / \mathrm{g}$ versus noninoculated flats $(1.3 \%)$. Total dampingoff at 50,000 CFU/g (40.5\%) was not significantly different than at $10,000 \mathrm{CFU} / \mathrm{g}$ $(30.8 \%)$ but less than at $100,000 \mathrm{CFU} / \mathrm{g}$ $(88.4 \%$ ) (Fig. 1C). In trial 2, emergence in noninoculated flats, which reached $92.2 \%$ by 35 dap, was greater than in inoculated flats each week (data not shown). Final emergence was not significantly different from 10,000 to $50,000 \mathrm{CFU} / \mathrm{g}$ (68.9 to $75.6 \%$ ), but was significantly less at $75,000 \mathrm{CFU} / \mathrm{g}$ (40.6\%) (Fig. 1D). Preemergence damping-off was not significantly different from 10,000 to 50,000 CFU/g (16.1 to $22.8 \%$ ) by 35 dap, but was greatest at $75,000 \mathrm{CFU} / \mathrm{g}(51.1 \%$ by 35 dap) (Fig. 1D). In contrast, postemergence damping-off was not significantly different at 25,000 to 75,000 CFU/g (18.4 to $20.2 \%$ ). Total damping-off 35 dap was not significantly different at 25,000 and $50,000 \mathrm{CFU} / \mathrm{g}$ (35.2 to $43.0 \%$, respectively), but was greater at 75,000 CFU/g
(69.5\%) (Fig. 1D). Dry spinach biomass declined significantly with increasing inoculum concentration, but was not significantly different at 10,000 to 50,000 $\mathrm{CFU} / \mathrm{g}$ (2.68 to $3.22 \mathrm{~g}$ ). Biomass was greatest in the noninoculated flats $(4.08$ g) and least at 75,000 CFU/g (1.62 g) (data not shown).

Inoculation with $F$. oxysporum f. sp. spinaciae did not significantly affect emergence or preemergence damping-off, but inoculum concentration significantly affected postemergence wilt and total wilt from 21 to 32 dap in trial 1 (Fig. 1E), and 28 to 56 dap in trial 2 (Fig. 1F). In trial 1, emergence 32 dap ranged from 83.3 to $89.4 \%$ across all treatments (Fig. 1E). Postemergence wilt was first observed 14 dap, but a majority of wilt did not develop until 21 to 32 dap. Postemergence wilt 32 dap was not significantly different at 50,000 to $500,000 \mathrm{CFU} / \mathrm{g}$ (91.8 to $100 \%$ ), but was less at 10,000 CFU/g (52.1\%), and significantly less than in noninoculated flats
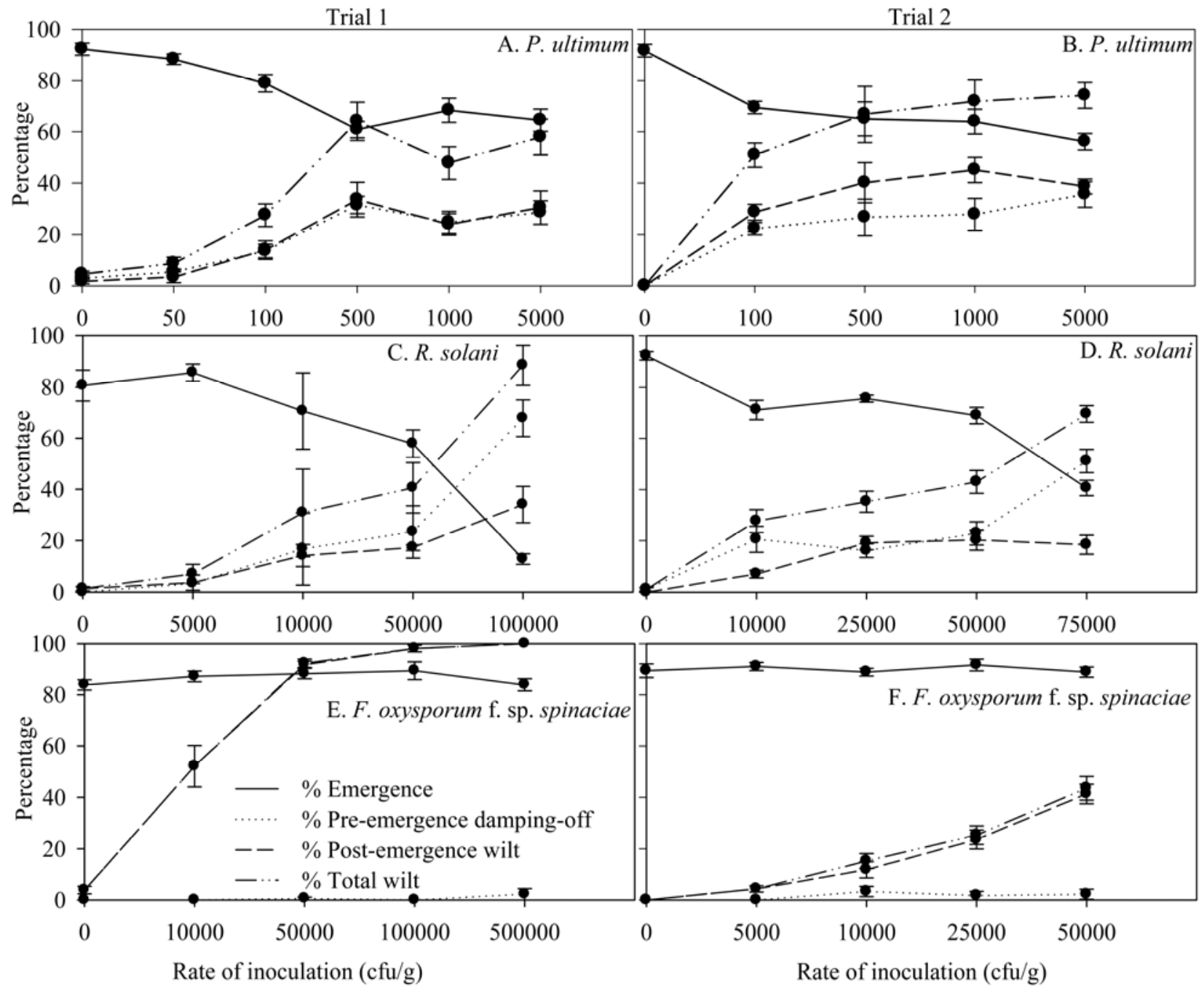

Fig. 1. Emergence, preemergence damping-off, postemergence wilt, and total disease (pre- and postemergence) caused by Pythium ultimum (A and B), Rhizoctonia solani (C and D), and Fusarium oxysporum f. sp. spinaciae (E and F) in greenhouse trials evaluating the effect of inoculum concentration on spinach seedlings. Emergence and disease were measured weekly, with results shown for the final rating. For P. ultimum, trial 1 (A) was completed over 32 days, and trial 2 (B) over 35 days, each at $25 \pm 5^{\circ} \mathrm{C}$. For $R$. solani, trial 1 (C) was completed over 32 days, and trial $2(\mathbf{D})$ over 35 days, each at $25 \pm 5^{\circ} \mathrm{C}$. For F. oxysporum $\mathrm{f}$. sp. spinaciae, trial 1 (E) was completed over 32 days at $25 \pm 5^{\circ} \mathrm{C}$, and trial 2 (F) over 56 days at $28 \pm 5^{\circ} \mathrm{C}$. Each data point is the mean \pm standard error of five replications. 
(3.9\%). In trial 2, emergence 56 dap was not significantly different among inoculum concentrations (88.9 to $91.7 \%$, Fig. 1F). Preemergence damping-off was only $1.4 \%$ across all treatments. Postemergence and total wilt averaged 41.3 and $43.5 \%$, respectively, at 50,000 CFU/g, and only 11.8 and $15.2 \%$, respectively, at 10,000 CFU/g. Seedling biomass at 0,5,000, and 10,000 CFU/g was not significantly different (19.59 to $21.75 \mathrm{~g}$ ), but was less than at 25,000 and
50,000 CFU/g (16.95 and $14.92 \mathrm{~g}$, respectively) (data not shown).

Damping-off caused by $P$. ultimum was $43.5 \pm 6.4 \%$ in trial 1 and $71.9 \pm 8.4 \%$ in trial 2 for flats inoculated at $1,000 \mathrm{CFU} / \mathrm{g}$ (Fig. 1A and B). Therefore, 1,000 CFU/g was selected as the inoculation rate for the $P$. ultimum seed and drench treatment trials. For $R$. solani, 50,000 CFU/g was selected because this concentration resulted in $40.5 \pm 9.9 \%$ damping-off in trial 1 and
$43.0 \pm 4.5 \%$ in trial 2 (Fig. $1 C$ and D). Wilt caused by $F$. oxysporum f. sp. spinaciae at $10,000 \mathrm{CFU} / \mathrm{g}$ was $52.1 \pm 8.0 \%$ in trial 1 but only $15.2 \pm 2.9 \%$ in trial 2 (Fig. $1 \mathrm{E}$ and F).

$P$. ultimum seed and drench treatment trials. Inoculation of potting medium with $1,000 \mathrm{CFU} / \mathrm{g}$ of $P$. ultimum differentiated efficacy of the seed and drench treatments in both trials (Table 2). The treatments had a significant effect on emergence, preemergence damping-off, and postemer-

Table 2. Greenhouse evaluation of seed and drench treatments for management of damping-off caused by Pythium ultimum in organic spinach ${ }^{\mathrm{u}}$

\begin{tabular}{|c|c|c|c|c|c|}
\hline \multirow[b]{2}{*}{ Trial and treatment ${ }^{\mathrm{w}}$} & \multirow{2}{*}{$\begin{array}{l}\text { Seed or drench } \\
\text { application }^{x}\end{array}$} & \multirow{2}{*}{$\begin{array}{l}\% \text { Emergence } \\
\text { ( } 28 \text { or } 35 \text { days) }\end{array}$} & \multicolumn{2}{|c|}{$\%$ Damping-off ( 28 or 35 days) ${ }^{v}$} & \multirow{2}{*}{$\begin{array}{l}\text { Total dry weight } \\
(\mathrm{g}, 28 \text { or } 35 \text { days })^{y}\end{array}$} \\
\hline & & & Preemergence & Postemergence & \\
\hline \multicolumn{6}{|l|}{ Trial 1} \\
\hline Compost tea & Drench & $80.0 \mathrm{~b}$ & $11.1 \mathrm{e}$ & $16.6 \mathrm{e}$ & $4.09 \mathrm{c}$ \\
\hline GTG I & Seed treatment & $95.6 \mathrm{a}$ & $0.0 \mathrm{f}$ & $3.5 \mathrm{fg}$ & $5.39 \mathrm{ab}$ \\
\hline GTG II & Seed treatment & $95.6 \mathrm{a}$ & $0.6 \mathrm{f}$ & $6.4 \mathrm{f}$ & $6.06 \mathrm{a}$ \\
\hline $\begin{array}{l}\text { Kodiak Concentrate Biological } \\
\text { Fungicide }\end{array}$ & Seed treatment & $79.5 \mathrm{~b}$ & $11.1 \mathrm{e}$ & $43.5 \mathrm{~cd}$ & $2.61 \mathrm{~d}$ \\
\hline $\begin{array}{l}\text { Micro } 108 \text { Seed Inoculant + } \\
\text { Actinovate AG }\end{array}$ & Seed treatment + drench & $67.2 \mathrm{de}$ & $23.3 \mathrm{bc}$ & $41.3 \mathrm{~d}$ & $2.30 \mathrm{def}$ \\
\hline Mycostop Mix Biofungicide & Seed treatment & $67.8 \mathrm{de}$ & $22.8 \mathrm{bc}$ & $59.4 \mathrm{ab}$ & $1.87 \mathrm{f}$ \\
\hline Natural II & Seed treatment & $93.9 \mathrm{a}$ & $1.7 \mathrm{f}$ & $0.6 \mathrm{~g}$ & $4.49 \mathrm{bc}$ \\
\hline Natural X & Seed treatment & $90.6 \mathrm{a}$ & $2.8 \mathrm{f}$ & $7.4 \mathrm{f}$ & $4.03 \mathrm{c}$ \\
\hline PGPR Galaxy & Seed treatment & 71.1 bcde & $19.5 \mathrm{bcd}$ & $51.8 \mathrm{abcd}$ & $2.30 \mathrm{def}$ \\
\hline Prestop Biofungicide Powder & Drench & $47.8 \mathrm{f}$ & $42.8 \mathrm{a}$ & $57.3 \mathrm{ab}$ & $0.85 \mathrm{~g}$ \\
\hline SoilGard 12G Microbial Fungicide & Drench & $64.4 \mathrm{e}$ & $26.1 \mathrm{ab}$ & $41.4 \mathrm{~d}$ & $2.41 \mathrm{def}$ \\
\hline Subtilex Biological Fungicide & Seed treatment & $75.0 \mathrm{bcd}$ & $15.6 \mathrm{cde}$ & $50.6 \mathrm{abcd}$ & $2.56 \mathrm{de}$ \\
\hline T-22 Planter Box Biological Fungicide & Seed treatment + drench & 69.4 cde & $21.1 \mathrm{bcd}$ & $54.7 \mathrm{abc}$ & $1.99 \mathrm{def}$ \\
\hline $\begin{array}{l}\text { Yield Shield Concentrate Biological } \\
\text { Fungicide }\end{array}$ & Seed treatment & $78.3 \mathrm{bc}$ & $12.2 \mathrm{e}$ & $61.3 \mathrm{a}$ & 1.95 ef \\
\hline Apron XL LS & Seed treatment & $94.4 \mathrm{a}$ & $0.0 \mathrm{f}$ & $2.4 \mathrm{fg}$ & $5.07 \mathrm{~b}$ \\
\hline Nontreated seed in inoculated medium & - & $77.8 \mathrm{bc}$ & $12.8 \mathrm{de}$ & $48.5 \mathrm{bcd}$ & $2.28 \mathrm{def}$ \\
\hline $\begin{array}{l}\text { Nontreated seed in noninoculated } \\
\text { medium }\end{array}$ & - & 90.6 a & $0.0 \mathrm{f}$ & $3.7 \mathrm{fg}$ & $4.55 \mathrm{bc}$ \\
\hline $\operatorname{LSD}(P<0.05)^{\mathrm{z}}$ & & 9.09 & Rank & Square root & $\log$ \\
\hline \multicolumn{6}{|l|}{ Trial 2} \\
\hline Compost tea & Drench & $62.8 \mathrm{de}$ & $28.9 \mathrm{ab}$ & 47.2 abcde & $1.24 \mathrm{~g}$ \\
\hline GTG I & Seed treatment & $92.2 \mathrm{a}$ & $0.6 \mathrm{e}$ & $15.8 \mathrm{gh}$ & $4.37 \mathrm{ab}$ \\
\hline GTG II & Seed treatment & $95.6 \mathrm{a}$ & $0.0 \mathrm{e}$ & $29.5 \mathrm{fgh}$ & $3.70 \mathrm{bc}$ \\
\hline $\begin{array}{l}\text { Kodiak Concentrate Biological } \\
\text { Fungicide }\end{array}$ & Seed treatment & $72.2 \mathrm{bc}$ & $19.4 \mathrm{~cd}$ & $31.1 \mathrm{defg}$ & $3.09 \mathrm{~cd}$ \\
\hline $\begin{array}{l}\text { Micro } 108 \text { Seed Inoculant + } \\
\text { Actinovate AG }\end{array}$ & Seed treatment + drench & $73.9 \mathrm{~b}$ & $17.8 \mathrm{~d}$ & 34.4 bcdefg & $2.65 \mathrm{cde}$ \\
\hline Mycostop Mix Biofungicide & Seed treatment & $73.3 \mathrm{~b}$ & $18.3 \mathrm{~d}$ & 36.7 bcdef & $2.80 \mathrm{~cd}$ \\
\hline Natural II & Seed treatment & $54.5 \mathrm{e}$ & $37.2 \mathrm{a}$ & $64.1 \mathrm{a}$ & $1.24 \mathrm{~g}$ \\
\hline Natural X & Seed treatment & $68.3 \mathrm{bc}$ & $23.3 \mathrm{~cd}$ & $32.2 \mathrm{efg}$ & $2.70 \mathrm{cde}$ \\
\hline PGPR Galaxy & Seed treatment & $71.1 \mathrm{bc}$ & $20.6 \mathrm{~cd}$ & 30.1 efg & $2.78 \mathrm{~cd}$ \\
\hline Prestop Biofungicide Powder & Drench & $55.6 \mathrm{de}$ & $36.1 \mathrm{ab}$ & $54.1 \mathrm{ab}$ & $1.34 \mathrm{fg}$ \\
\hline SoilGard 12G Microbial Fungicide & Drench & $48.3 \mathrm{e}$ & $43.3 \mathrm{a}$ & $51.6 \mathrm{abcd}$ & $1.40 \mathrm{fg}$ \\
\hline Subtilex Biological Fungicide & Seed treatment & $85.6 \mathrm{a}$ & $6.7 \mathrm{e}$ & $11.2 \mathrm{hi}$ & $3.06 \mathrm{~cd}$ \\
\hline T-22 Planter Box Biological Fungicide & Seed treatment + drench & $72.8 \mathrm{~b}$ & $18.9 \mathrm{~d}$ & $57.8 \mathrm{a}$ & 1.76 efg \\
\hline $\begin{array}{l}\text { Yield Shield Concentrate Biological } \\
\text { Fungicide }\end{array}$ & Seed treatment & $66.1 \mathrm{~cd}$ & $25.6 \mathrm{bc}$ & $53.2 \mathrm{abc}$ & $2.16 \mathrm{def}$ \\
\hline Apron XL LS & Seed treatment & $91.1 \mathrm{a}$ & $1.7 \mathrm{e}$ & $3.7 \mathrm{ij}$ & $4.61 \mathrm{ab}$ \\
\hline Nontreated seed in inoculated medium & - & $72.2 \mathrm{bc}$ & $19.4 \mathrm{~cd}$ & 33.0 cdefg & $2.82 \mathrm{~cd}$ \\
\hline $\begin{array}{l}\text { Nontreated seed in noninoculated } \\
\text { medium }\end{array}$ & - & $91.7 \mathrm{a}$ & $0.0 \mathrm{e}$ & $1.8 \mathrm{j}$ & $5.20 \mathrm{a}$ \\
\hline $\operatorname{LSD}(P<0.05)^{\mathrm{z}}$ & & Rank & Rank & Arcsin & Arcsin \\
\hline
\end{tabular}

"A randomized complete block design with five replications was used for each trial. The number of emerged seedlings and number of wilted seedlings was recorded weekly for 4 or 5 weeks. Results are shown for the final rating (35 and 28 days after planting for trials 1 and 2, respectively).

${ }^{\mathrm{v}}$ Preemergence damping-off $=$ percent nonemerged seedlings in each flat compared to the noninoculated control flat in each replication. Postemergence damping-off $=$ percent emerged seedlings in each flat that died or exhibited damping-off. Total damping-off $=$ pre- + postemergence damping-off .

${ }^{w}$ Not all products were EPA-registered or reviewed for compliance with the USDA National Organic Program (NOP) or the Organic Materials Review Institute (OMRI) in 2007. Refer to Table 1 for details of the treatments. Apron XL LS (mefenoxam) was included as a conventional fungicide seed treatment for control of P. ultimum. For both control treatments, the seed was not treated. For all treatments except nontreated seed planted into noninoculated medium, seed was planted into potting mix inoculated with $P$. ultimum at $1,000 \mathrm{CFU} / \mathrm{g}(\mathrm{wt} / \mathrm{wt})$.

${ }^{x}$ Refer to Table 1 for details on method of drench and/or seed treatment for each product.

${ }^{\mathrm{y}}$ Biomass $=$ aboveground dry weight of all emerged seedlings in each flat at the final rating.

${ }^{\mathrm{z}}$ LSD $=$ Fisher's protected least significant difference. Means followed by the same letter within a column are not significantly different. 'Log', 'square root', 'arcsin', or 'rank': original means are presented but means separation by LSD was based on transformation (logarithmic, square root, or arcsin square root transformation) or Friedman's nonparametric rank test, respectively, because of heterogeneous variances and/or non-normal distribution of residuals. 
gence damping-off in each trial for all weekly ratings compared with nontreated seed in noninoculated medium $(P<0.05)$, with the exception of postemergence damping-off 7 dap. The treatments had a similar effect on AUEPC, AUDPC pre, $_{\text {AUDPC }}$ post, and $\mathrm{AUDPC}_{\text {total }}$ (data not shown).

In flats planted with seeds treated with GTG I and GTG II, seedlings first emerged 4 dap, whereas seedlings did not emerge until 5 dap or later for other treatments (data not shown). In trial 1, emergence 35 dap for the GTG I, GTG II, Natural II, and Natural X seed treatments was not significantly different than that of Apron XL LS seed treatment or nontreated seed in noninoculated flats, but was significantly greater than that of nontreated seed in inoculated flats (Table 2). In contrast, $P$. ultimum significantly reduced seedling emergence in flats with the Prestop, Micro 108, Mycostop Mix, and SoilGard 12G treatments compared with nontreated seeds. Preemergence damping-off 35 dap in the GTG I, GTG II, Natural II, and Natural X treatments was similar to that of Apron XL LS seed treatment (Table 2), but was significantly greater in the Micro 108, Mycostop Mix, Prestop, and SoilGard treatments compared with nontreated seed in inoculated flats. Postemergence damping-off was first observed 7 dap. P. ultimum caused significantly less postemergence damping-off $(<8.0 \%)$ for seed treated with GTG I, GTG II, Natural II, and Natural $X$ than for nontreated seed in inoculated flats, and was similar to that of seed treated with Apron XL LS (Table 2). The compost tea drench also significantly reduced postemergence damping-off compared with noninoculated seed in inoculated flats. In contrast, $P$. ultimum caused greater postemergence damping-off 35 dap in flats with Yield Shield, Mycostop Mix, Prestop, T-22 Planter Box, PGPR Galaxy, and Subtilex (all $>50 \%$ ) (Table 2). Spinach biomass 35 dap was greatest in flats with GTG I and GTG II seed treatments (Table 2). GTG II resulted in significantly greater biomass compared with that of nontreated seed and Apron XL LS seed treatment. Flats with GTG I and Natural II treatments had spinach biomass similar to flats with Apron XL LS. P. ultimum significantly reduced seedling biomass only in flats drenched with Prestop compared with nontreated seed in inoculated flats.

In trial 2, total damping-off 28 dap for nontreated seed planted in inoculated flats was $52.6 \pm 4.8 \%$ (Table 2). Emergence was first observed 4 dap in flats with GTG I or GTG II seed treatments, and after at least 5 dap for other treatments. Emergence of seedlings in the GTG I, GTG II, and Subtilex treatments was statistically similar to that of Apron XL LS-treated seed, as well as nontreated seed in noninoculated flats. However, emergence in flats with compost tea, Natural II, Prestop, and SoilGard 12G was significantly less compared with that of nontreated seed in inoculated flats (Table 2). Preemergence damping-off 28 dap in flats with GTG I, GTG II, and Subtilex treatments was similar to that of nontreated seed in noninoculated flats and Apron XL LS-treated seed in inoculated flats. In contrast, preemergence damping-off 28 dap was significantly greater in flats with compost tea, Natural II, Prestop, and SoilGard 12G treatments compared with that of nontreated seed (Table 2). Postemergence damping-off in trial 2 was first observed 7 dap. By 28 dap, postemergence damping-off in flats with the Subtilex seed treatment was similar to that of Apron XL LS-treated seed. In contrast, postemergence dampingoff 28 dap was significantly greater in flats with Natural II, Prestop, and T-22 Planter Box treatments. Spinach biomass from GTG I-treated seed was not significantly different from that of nontreated seed in noninoculated flats or Apron XL LS-treated seed (Table 2). In addition, biomass of seedlings from seed treated with GTG II (3.70 \pm $0.67 \mathrm{~g}$ ) was similar to that in the Apron XL LS treatment. Spinach biomass in flats with compost tea, Natural II, Prestop, SoilGard 12G, and T-22 Planter Box was significantly less than that of nontreated seed in inoculated flats.

$R$. solani seed and drench treatment trials. The 50,000 CFU/g rate of inoculation in the first $R$. solani trial resulted in $74.6 \pm 3.9 \%$ total damping-off 28 dap for nontreated seed in inoculated flats, which was greater than the targeted $50 \%$ damping-off. However, for trial 2, with 25,000 $\mathrm{CFU} / \mathrm{g}$, total damping-off for nontreated seed in inoculated flats was only $6.4 \pm$ $2.8 \%$ by 28 dap. Seed and drench treatments had a significant $(P<0.05)$ effect on emergence, preemergence damping-off, and postemergence damping-off for all weekly ratings in trial 1 , except postemergence damping-off 7 dap. In trial 2, the treatments significantly affected emergence as well as preemergence dampingoff for all weekly ratings, but not postemergence damping-off. The treatments also significantly affected AUEPC, $\mathrm{AUDPC}_{\text {pre }}$, and $\mathrm{AUDPC}_{\text {total }}$, in each trial and $\mathrm{AUDPC}_{\text {post }}$ in trial 1 but not in trial 2 (data not shown). The treatments significantly affected spinach biomass (Table 3 ).

Due, in part, to a low incidence of damping-off in trial 2, limited similarities were evident between the two trials with $R$. solani (Table 3 ). In both trials, emergence was first observed 4 dap in flats planted with seed treated with GTG I or GTG II, but not until at least 5 dap for the other treatments. In trial 1, final emergence in flats with nontreated seed was $91.0 \pm 2.1 \%$ in noninoculated flats versus $23.6 \pm 8.1 \%$ in inoculated flats. Only GTG I and Natural II treatments resulted in final emergence ratings similar to that of the Terraclor-drenched flats, all of which were significantly greater than that of nontreated seed in inoculated flats. Compost tea, GTG
II, Natural X, Prestop, and Subtilex treatments significantly increased emergence compared with nontreated seed in inoculated flats. Preemergence damping-off was similar in flats with GTG I, Natural II, and Terraclor treatments, all of which had significantly less preemergence damping-off than inoculated flats with nontreated seed (Table 3). In addition, preemergence damping-off in flats with compost tea, GTG II, Natural X, Prestop, and Subtilex was significantly less than in flats with nontreated seed. In contrast, preemergence damping-off was significantly greater in Yield Shield-treated flats. Postemergence damping-off in trial 1 was first observed 6 dap, and by 28 dap was greater in flats with Mycostop Mix, SoilGard 12G, Subtilex, and T-22 Planter Box treatments compared with nontreated seed in inoculated flats (Table 3). Postemergence damping-off was not recorded in flats with Yield Shield, as no seedlings emerged. No treatment significantly reduced postemergence damping-off compared with nontreated seed or the Terraclor drench. Spinach biomass in trial 1 was greatest for seedlings that developed from seed treated with GTG I or Natural X, similar to Terraclordrenched flats and nontreated seed in noninoculated flats (Table 3). Seedlings from flats with compost tea, GTG II, Natural II, and T-22 Planter Box had significantly greater biomass than that of nontreated seed in inoculated flats.

In trial 2, emergence of nontreated seed was not affected by inoculum (Table 3 ). In addition, no treatment significantly increased emergence compared with the control treatments, but emergence in flats with compost tea, Prestop, SoilGard 12G, and T-22 Planter Box was significantly less than emergence from nontreated seed in inoculated flats. Preemergence dampingoff 28 dap was significantly greater in flats with compost tea, PGPR Galaxy, Prestop, and SoilGard 12G compared with nontreated seed. No significant differences in postemergence damping-off were detected among treatments because of low disease pressure. No treatment significantly improved spinach biomass compared with biomass from flats with nontreated seed, but biomass from flats with compost tea, Kodiak, Micro 108, Natural X, Prestop, SoilGard 12G, Subtilex, Yield Shield, and Terraclor treatments was reduced (Table 3 ).

F. oxysporum f. sp. spinaciae seed and drench treatment trials. Total dampingoff for nontreated seed planted in inoculated flats was $42.9 \pm 7.3 \%$ by 42 dap in trial 1 , and $29.9 \pm 6.9 \%$ in trial 2 (Table 4). Emergence was first observed 4 dap in flats planted with seed treated with GTG I or GTG II, but not until at least 5 dap for the other treatments. In trial 1, emergence 42 dap was similar for the nontreated seed in inoculated versus noninoculated flats (Table 4). By 42 dap, none of the treat- 
ments significantly increased emergence compared with flats with Mertect 340F seed treatment or nontreated seed. T-22 Planter Box, Micro 108, Prestop, SoilGard $12 \mathrm{G}$, and Yield Shield treatments reduced emergence significantly compared with nontreated seed. Preemergence dampingoff in trial 1 was low but significantly greater in flats with Micro 108, SoilGard 12G, T-22 Planter Box, and Yield Shield treatments compared with flats with nontreated seed (Table 4). Preemergence damping-off in flats with all other treatments was similar to that of Mertect $340 \mathrm{~F}$ and nontreated seed. Postemergence wilt in trial 1 was first observed 28 dap. By 42 dap, Prestop and Yield Shield flats significantly reduced postemergence wilt, whereas postemergence wilt was significantly greater in flats with GTG I, GTG II, Kodiak, PGPR Galaxy, SoilGard 12G, and T-22 Planter Box treatments (Table 4). Spinach dry biomass in trial 1 was greater in flats with compost tea, Prestop, Subtilex, or Yield Shield treatments compared with nontreated seed and Mertect 340Ftreated seed (Table 4). Spinach biomass was significantly less in the flats with SoilGard 12G and T-22 Planter Box treatments. Seed and drench treatments had a significant effect $(P<0.05)$ on AUEPC, $\mathrm{AUDPC}_{\text {pre }}, \mathrm{AUDPC}_{\text {post }}$, and $\mathrm{AUDPC}_{\text {total }}$, similar to final emergence and wilt ratings (data not shown).

In trial 2, only Micro 108 and Prestop treatments significantly reduced emergence compared with that of nontreated seed. Preemergence damping-off 49 dap was significantly greater in the Micro 108 and Prestop flats compared with nontreated seed (Table 4). Preemergence damping-off in flats with other treatments was similar to that of nontreated seed or the Mertect 340F-treated seed. Postemergence wilt was first observed 14 dap in

Table 3. Greenhouse evaluation of seed and drench treatments for management of damping-off caused by Rhizoctonia solani in organic spinach ${ }^{\mathrm{u}}$

\begin{tabular}{|c|c|c|c|c|c|}
\hline \multirow[b]{2}{*}{ Treatment $^{w}$} & \multirow{2}{*}{$\begin{array}{l}\text { Seed or drench } \\
\text { application }^{x}\end{array}$} & \multirow{2}{*}{$\begin{array}{l}\% \text { Emergence } \\
\text { (28 days) }\end{array}$} & \multicolumn{2}{|c|}{$\%$ Damping-off (28 days) ${ }^{\mathrm{v}}$} & \multirow{2}{*}{$\begin{array}{l}\text { Total dry weigh } \\
\quad(g, 28 \text { days })^{y}\end{array}$} \\
\hline & & & Preemergence & Postemergence & \\
\hline \multicolumn{6}{|l|}{ Trial 1} \\
\hline Compost tea & Drench & $44.4 \mathrm{~cd}$ & $46.5 \mathrm{fg}$ & 15.7 abcde & 1.78 bcdef \\
\hline GTG I & Seed treatment & $63.9 \mathrm{ab}$ & $27.1 \mathrm{hi}$ & 11.7 bcdef & $3.89 \mathrm{a}$ \\
\hline GTG II & Seed treatment & $41.0 \mathrm{~cd}$ & $50.0 \mathrm{fg}$ & 16.5 abcd & $1.75 \mathrm{bcd}$ \\
\hline Kodiak Concentrate Biological Fungicide & Seed treatment & $22.9 \mathrm{fgh}$ & $68.1 \mathrm{bcd}$ & 17.1 abcd & 0.97 fghij \\
\hline Micro 108 Seed Inoculant + Actinovate AG & Seed treatment + drench & $27.1 \mathrm{fgh}$ & $63.9 \mathrm{bcd}$ & 11.8 bcdef & 0.81 ghij \\
\hline Mycostop Mix Biofungicide & Seed treatment & $20.1 \mathrm{ghi}$ & $70.8 \mathrm{abc}$ & $22.9 \mathrm{abc}$ & $0.60 \mathrm{ijk}$ \\
\hline Natural II & Seed treatment & $65.6 \mathrm{abc}$ & $27.2 \mathrm{ghi}$ & 8.5 cdef & $2.17 \mathrm{bcde}$ \\
\hline Natural X & Seed treatment & 41.7 bcd & $48.2 \mathrm{fgh}$ & 13.4 bcdef & $2.03 \mathrm{abc}$ \\
\hline PGPR Galaxy & Seed treatment & $16.0 \mathrm{hi}$ & $75.0 \mathrm{ab}$ & 11.3 cdef & $0.53 \mathrm{jk}$ \\
\hline Prestop Biofungicide Powder & Drench & $34.7 \mathrm{de}$ & $56.3 \mathrm{ef}$ & $7.1 \mathrm{def}$ & 1.31 efgh \\
\hline SoilGard 12G Microbial Fungicide & Drench & 32.6 def & 58.3 def & $22.2 \mathrm{abc}$ & 1.04 fghi \\
\hline Subtilex Biological Fungicide & Seed treatment & $38.9 \mathrm{de}$ & $52.1 \mathrm{ef}$ & $26.2 \mathrm{ab}$ & 1.19 defgh \\
\hline T-22 Planter Box Biological Fungicide & Seed treatment + drench & $27.8 \mathrm{efg}$ & 63.2 cde & $28.9 \mathrm{a}$ & 1.47 cdefg \\
\hline $\begin{array}{l}\text { Yield Shield Concentrate Biological } \\
\text { Fungicide }\end{array}$ & Seed treatment & $0.0 \mathrm{i}^{\circ}$ & $91.0 \mathrm{a}$ & $0.0 \mathrm{f}$ & $0.00 \mathrm{k}$ \\
\hline Terraclor $75 \% \mathrm{WP}$ & Drench & $81.3 \mathrm{a}$ & $10.4 \mathrm{i}$ & $1.7 \mathrm{ef}$ & $3.54 \mathrm{a}$ \\
\hline Nontreated seed in inoculated medium & - & $23.6 \mathrm{fgh}$ & $67.4 \mathrm{bcd}$ & 7.2 def & 0.76 hijk \\
\hline $\begin{array}{l}\text { Nontreated seed in noninoculated } \\
\text { medium }\end{array}$ & - & $91.0 \mathrm{a}$ & $0.0 \mathrm{i}$ & $1.5 \mathrm{ef}$ & $2.57 \mathrm{ab}$ \\
\hline $\operatorname{LSD}(P<0.05)^{\mathrm{z}}$ & & Rank & Rank & 14.54 & Rank \\
\hline \multicolumn{6}{|l|}{ Trial 2} \\
\hline Compost tea & Drench & $65.0 \mathrm{f}$ & $15.0 \mathrm{a}$ & $4.7 \mathrm{a}$ & $1.92 \mathrm{i}$ \\
\hline GTG I & Seed treatment & $79.4 \mathrm{abc}$ & 5.0 bcde & $3.4 \mathrm{a}$ & $4.74 \mathrm{ab}$ \\
\hline GTG II & Seed treatment & $78.3 \mathrm{abcd}$ & 3.9 cde & $7.6 \mathrm{a}$ & $4.78 \mathrm{ab}$ \\
\hline Kodiak Concentrate Biological Fungicide & Seed treatment & $80.0 \mathrm{abc}$ & 5.0 cde & $4.9 \mathrm{a}$ & 4.08 bcde \\
\hline Micro 108 Seed Inoculant + Actinovate AG & Seed treatment + drench & $78.9 \mathrm{abc}$ & 5.6 abcde & $7.4 \mathrm{a}$ & 3.92 cde \\
\hline Mycostop Mix Biofungicide & Seed treatment & $85.6 \mathrm{a}$ & $0.6 \mathrm{e}$ & $4.0 \mathrm{a}$ & $4.18 \mathrm{abcd}$ \\
\hline Natural II & Seed treatment & $81.1 \mathrm{abc}$ & 3.3 cde & $3.4 \mathrm{a}$ & $4.42 \mathrm{abc}$ \\
\hline Natural X & Seed treatment & 73.9 bcdef & 5.0 abcde & $6.5 \mathrm{a}$ & $3.52 \mathrm{def}$ \\
\hline PGPR Galaxy & Seed treatment & 75.6 abcde & $9.5 \mathrm{abc}$ & $7.0 \mathrm{a}$ & $4.24 \mathrm{abcd}$ \\
\hline Prestop Biofungicide Powder & Drench & $66.1 \mathrm{ef}$ & $12.8 \mathrm{ab}$ & $6.2 \mathrm{a}$ & $2.47 \mathrm{hi}$ \\
\hline SoilGard 12G Microbial Fungicide & Drench & 68.3 def & $10.0 \mathrm{abc}$ & $7.4 \mathrm{a}$ & $3.10 \mathrm{fgh}$ \\
\hline Subtilex Biological Fungicide & Seed treatment & 75.0 bcdef & 6.1 bcde & $8.4 \mathrm{a}$ & 3.77 cdef \\
\hline T-22 Planter Box Biological Fungicide & Seed treatment + drench & 72.2 cdef & 8.9 abcd & $3.4 \mathrm{a}$ & $4.27 \mathrm{abcd}$ \\
\hline $\begin{array}{l}\text { Yield Shield Concentrate Biological } \\
\text { Fungicide }\end{array}$ & Seed treatment & $80.6 \mathrm{abc}$ & 2.8 bcde & $11.5 \mathrm{a}$ & 3.85 cdef \\
\hline Terraclor $75 \%$ WP & Drench & $81.1 \mathrm{abc}$ & 2.3 bcde & $0.7 \mathrm{a}$ & $2.70 \mathrm{ghi}$ \\
\hline Nontreated seed in inoculated medium & - & $82.8 \mathrm{ab}$ & $1.7 \mathrm{de}$ & $4.7 \mathrm{a}$ & $4.93 \mathrm{a}$ \\
\hline $\begin{array}{l}\text { Nontreated seed in noninoculated } \\
\text { medium }\end{array}$ & - & $78.3 \mathrm{abcd}$ & $0.0 \mathrm{e}$ & $1.6 \mathrm{a}$ & $3.28 \mathrm{efg}$ \\
\hline $\operatorname{LSD}(P<0.05)^{\mathrm{z}}$ & & 10.36 & Rank & NS & 0.806 \\
\hline
\end{tabular}

u A randomized complete block design with four or five replications was used (trials 1 and 2, respectively). The number of emerged seedlings and number of wilted seedlings was recorded at weekly intervals for four weeks. Results are shown for the final rating (28 days).

${ }^{\mathrm{v}}$ Preemergence damping-off $=$ percent nonemerged seedlings in each flat compared to the noninoculated control flats in each replication. Postemergence damping-off $=$ percent emerged seedlings in each flat that died or exhibited damping-off symptoms. Total damping-off $=$ pre- + postemergence damping-off.

${ }^{w}$ Not all products were EPA-registered or reviewed for compliance with the USDA National Organic Program (NOP) or the Organic Materials Review Institute (OMRI) in 2007. Refer to Table 1 for details of the treatments. Terraclor 75\% WP (pentachloronitrobenzene) was included as a conventional fungicide drench for control of $R$. solani. For both control treatments, the seed was not treated. For all treatments except nontreated seed planted into noninoculated medium, seed was planted into potting mix inoculated with $R$. solani at 50,000 or 25,000 CFU/g (wt/wt) in trials 1 and 2, respectively.

${ }^{x}$ Refer to Table 1 for details on method of drench and/or seed treatment for each product.

${ }^{\mathrm{y}}$ Biomass $=$ aboveground dry weight of all emerged seedlings in each flat at the final rating.

${ }^{\mathrm{z}}$ LSD $=$ Fisher's protected least significant difference. Means followed by the same letter within a column are not significantly different. 'Rank': original means are presented but means separation by LSD was based on Friedman's nonparametric rank test because of heterogeneous variances and/or non-normal distribution of residuals. 
trial 2 versus 28 dap in trial 1. Postemergence wilt 49 dap was significantly less in flats with compost tea and Prestop treatments compared with nontreated seed in inoculated flats (Table 4). Biomass of seedlings that developed from GTG Itreated seed was similar to that of seedlings that grew from nontreated seed in noninoculated flats and Mertect 340Ftreated seed, and was significantly greater than that of nontreated seed in inoculated flats (Table 4). In contrast, Micro 108 significantly reduced spinach biomass compared with that of nontreated seed.

Potting mix pH from treatment trials. The $\mathrm{pH}$ of the potting mix averaged 6.46 prior to planting the second $P$. ultimum trial and 6.40 prior to the second $F$. oxysporum f. sp. spinaciae trial. The $\mathrm{pH}$ at the end of the $F$. oxysporum f. sp. spinaciae trial also averaged 6.40 .

Seed health assays of treated seed. For the seed health assay of the first Lazio seed lot (trial 1), the incidence of Verticillium spp. detected was reduced significantly by GTG I (10.5\%), GTG II (0.8\%), Mycostop Mix (13.0\%), Natural II (4.8\%), Natural X (20.3\%), and Mertect 340F (0.8\%) compared with nontreated seed $(49.8 \%)$ (Table 5). In contrast, the incidence of Verticillium spp. was only $1.3 \%$ for the second seed lot (trial 2). In that seed lot, T-22
Planter Box and Mertect 340F reduced the incidence of Verticillium spp. to $0 \%$. Most isolates of Verticillium observed resembled $V$. dahliae, a wilt pathogen of spinach (11). The prevalence of seedborne Stemphylium botryosum, causal agent of Stemphylium leaf spot of spinach (19), was significantly greater on seed treated with GTG I for the first seed lot $(17.5 \%)$, and on seed treated with GTG I (11.3\%) and GTG II (9.5\%) for the second lot compared with nontreated seed. In comparison, S. botryosum was less prevalent on seed of the first lot treated with Mycostop Mix, Natural II, and Apron XL LS, but only by Mycostop Mix for the second lot. The prevalence of

Table 4. Greenhouse evaluation of seed and drench treatments for management of seedling wilt caused by Fusarium oxysporum f. sp. spinaciae in organic spinach $^{u}$

\begin{tabular}{|c|c|c|c|c|c|}
\hline \multirow[b]{2}{*}{ Treatment $^{\mathrm{w}}$} & \multirow{2}{*}{$\begin{array}{l}\text { Seed or drench } \\
\text { application }^{x}\end{array}$} & \multirow{2}{*}{$\begin{array}{l}\text { \% Emergence } \\
(42 \text { or } 49 \text { days) }\end{array}$} & \multicolumn{2}{|c|}{ \% Damping-off (42 or 49 days) ${ }^{\mathrm{v}}$} & \multirow{2}{*}{$\begin{array}{l}\text { Total dry weight } \\
(\mathrm{g}, 42 \text { or } 49 \text { days })^{y}\end{array}$} \\
\hline & & & Preemergence & Postemergence & \\
\hline \multicolumn{6}{|l|}{ Trial 1} \\
\hline Compost tea & Drench & 90.6 abcde & 5.0 bcdefg & $28.4 \mathrm{gh}$ & $6.64 \mathrm{a}$ \\
\hline GTG I & Seed treatment & $93.3 \mathrm{abcd}$ & $2.2 \mathrm{defg}$ & $56.5 \mathrm{abc}$ & 4.03 efg \\
\hline GTG II & Seed treatment & $93.8 \mathrm{abc}$ & $1.1 \mathrm{fg}$ & 54.0 abcd & $3.50 \mathrm{fgh}$ \\
\hline Kodiak Concentrate Biological Fungicide & Seed treatment & 90.6 abcde & 3.3 cdefg & $60.7 \mathrm{ab}$ & $3.21 \mathrm{ghi}$ \\
\hline Micro 108 Seed Inoculant + Actinovate AG & Seed treatment + drench & $83.3 \mathrm{ef}$ & $10.6 \mathrm{abcd}$ & 44.5 cdef & $3.00 \mathrm{hij}$ \\
\hline Mycostop Mix Biofungicide & Seed treatment & 92.8 abcd & 2.8 cdefg & 53.9 abcd & $3.32 \mathrm{gh}$ \\
\hline Natural II & Seed treatment & 88.3 bcde & 5.6 abcdef & 33.7 efgh & $4.23 \mathrm{def}$ \\
\hline Natural $\mathrm{X}$ & Seed treatment & $96.7 \mathrm{a}$ & $1.7 \mathrm{fg}$ & $43.3 \mathrm{cdefg}$ & 4.03 efg \\
\hline PGPR Galaxy & Seed treatment & 90.6 abcde & $6.7 \mathrm{bcdef}$ & $55.8 \mathrm{abc}$ & $3.23 \mathrm{ghi}$ \\
\hline Prestop Biofungicide Powder & Drench & $85.6 \mathrm{def}$ & 8.3 abcde & $25.5 \mathrm{~h}$ & $4.65 \mathrm{cde}$ \\
\hline SoilGard 12G Microbial Fungicide & Drench & 84.4 ef & $12.2 \mathrm{ab}$ & $66.5 \mathrm{a}$ & $2.40 \mathrm{ij}$ \\
\hline Subtilex Biological Fungicide & Seed treatment & 91.1 abcde & 3.9 cdefg & $33.2 \mathrm{fgh}$ & $5.06 \mathrm{bcd}$ \\
\hline T-22 Planter Box Biological Fungicide & Seed treatment + drench & $80.0 \mathrm{f}$ & $13.9 \mathrm{a}$ & $66.1 \mathrm{a}$ & $2.14 \mathrm{j}$ \\
\hline $\begin{array}{l}\text { Yield Shield Concentrate Biological } \\
\text { Fungicide }\end{array}$ & Seed treatment & $86.7 \mathrm{cdef}$ & $8.9 \mathrm{abc}$ & $22.3 \mathrm{hi}$ & $5.81 \mathrm{ab}$ \\
\hline Mertect $340 \mathrm{~F}$ & Seed treatment & 92.8 abcd & 3.3 cdefg & 48.3 bcde & $3.54 \mathrm{fgh}$ \\
\hline Nontreated seed in inoculated medium & - & $95.6 \mathrm{ab}$ & $2.2 \mathrm{efg}$ & $40.7 \mathrm{defg}$ & $3.48 \mathrm{fgh}$ \\
\hline Nontreated seed in noninoculated medium & - & $93.9 \mathrm{abc}$ & $0.0 \mathrm{~g}$ & $10.2 \mathrm{i}$ & $5.17 \mathrm{bc}$ \\
\hline $\operatorname{LSD}(P<0.05)^{\mathrm{z}}$ & & 7.95 & $\log$ & 14.97 & 0.908 \\
\hline \multicolumn{6}{|l|}{ Trial 2} \\
\hline Compost tea & Drench & $74.4 \mathrm{abc}$ & $7.8 \mathrm{cde}$ & $11.7 \mathrm{de}$ & $12.95 \mathrm{bcd}$ \\
\hline GTG I & Seed treatment & $73.9 \mathrm{abc}$ & $8.3 \mathrm{abc}$ & $19.1 \mathrm{~cd}$ & $13.71 \mathrm{ab}$ \\
\hline GTG II & Seed treatment & 67.8 cde & $13.3 \mathrm{bc}$ & $20.3 \mathrm{bcd}$ & $12.37 \mathrm{cde}$ \\
\hline Kodiak Concentrate Biological Fungicide & Seed treatment & $76.1 \mathrm{abc}$ & $8.9 \mathrm{abc}$ & $26.5 \mathrm{abc}$ & $11.60 \mathrm{ef}$ \\
\hline Micro 108 Seed Inoculant + Actinovate AG & Seed treatment + drench & $57.8 \mathrm{e}$ & $20.6 \mathrm{ab}$ & $26.6 \mathrm{abc}$ & $10.51 \mathrm{f}$ \\
\hline Mycostop Mix Biofungicide & Seed treatment & $73.3 \mathrm{bcd}$ & $6.7 \mathrm{~cd}$ & $24.3 \mathrm{abc}$ & $12.63 \mathrm{de}$ \\
\hline Natural II & Seed treatment & $83.9 \mathrm{ab}$ & 4.4 cde & $25.6 \mathrm{abc}$ & $12.40 \mathrm{de}$ \\
\hline Natural X & Seed treatment & $87.2 \mathrm{a}$ & $1.7 \mathrm{de}$ & $21.3 \mathrm{bcd}$ & $12.85 \mathrm{cde}$ \\
\hline PGPR Galaxy & Seed treatment & $80.6 \mathrm{abc}$ & 5.6 cde & $34.4 \mathrm{a}$ & $12.44 \mathrm{de}$ \\
\hline Prestop Biofungicide Powder & Drench & $60.0 \mathrm{de}$ & $20.0 \mathrm{a}$ & $11.6 \mathrm{de}$ & 11.74 ef \\
\hline SoilGard 12G Microbial Fungicide & Drench & $73.9 \mathrm{abc}$ & $9.4 \mathrm{~cd}$ & $31.8 \mathrm{ab}$ & $11.82 \mathrm{de}$ \\
\hline Subtilex Biological Fungicide & Seed treatment & $72.2 \mathrm{bcd}$ & $11.1 \mathrm{cde}$ & $29.5 \mathrm{abc}$ & $12.71 \mathrm{cde}$ \\
\hline T-22 Planter Box Biological Fungicide & Seed treatment + drench & $83.9 \mathrm{ab}$ & 1.7 cde & $26.0 \mathrm{abc}$ & $13.27 \mathrm{bcd}$ \\
\hline $\begin{array}{l}\text { Yield Shield Concentrate Biological } \\
\text { Fungicide }\end{array}$ & Seed treatment & $77.2 \mathrm{abc}$ & $6.7 \mathrm{cde}$ & $23.0 \mathrm{abcd}$ & 11.78 ef \\
\hline Mertect 340F & Seed treatment & $85.0 \mathrm{ab}$ & 3.3 cde & $21.9 \mathrm{bcd}$ & $13.44 \mathrm{abc}$ \\
\hline Nontreated seed in inoculated medium & - & $79.4 \mathrm{abc}$ & 3.9 cde & $26.1 \mathrm{abc}$ & $12.85 \mathrm{cde}$ \\
\hline Nontreated seed in noninoculated medium & - & $77.8 \mathrm{abc}$ & $0.0 \mathrm{e}$ & $0.7 \mathrm{e}$ & $14.90 \mathrm{a}$ \\
\hline $\operatorname{LSD}(P<0.05)^{\mathrm{z}}$ & & 13.44 & Rank & 12.19 & Rank \\
\hline
\end{tabular}

"A randomized complete block design with five replications was used for each trial. The number of emerged seedlings and the number of wilted seedlings was recorded weekly for 6 and 7 weeks in trials 1 and 2, respectively. Results are shown for the final rating (42 and 49 days for trials 1 and 2, respectively).

${ }^{\mathrm{v}}$ Preemergence damping-off $=$ percent nonemerged seedlings in each flat compared to the noninoculated control flat in each replication. Postemergence dampingoff $=$ percent emerged seedlings in each flat that died or exhibited damping-off symptoms. Total damping-off $=$ pre- + postemergence damping-off.

${ }^{w}$ Not all products were EPA-registered or reviewed for compliance with the USDA National Organic Program (NOP) or the Organic Materials Review Institute (OMRI) in 2007. Refer to Table 1 for details of the treatments. Mertect 340F (thiabendazole) was included as a conventional fungicide seed treatment for control of F. oxysporum f. sp. spinaciae. For both control treatments, the seed was not treated. For all treatments except nontreated seed planted into noninoculated medium, seed was planted into potting mix inoculated with $F$. oxysporum f. sp. spinaciae at 10,000 CFU/g (wt/wt).

${ }^{x}$ Refer to Table 1 for details on method of drench and/or seed treatment for each product.

${ }^{\mathrm{y}}$ Biomass $=$ aboveground dry weight of all emerged seedlings in each flat at the final rating.

${ }^{\mathrm{z}}$ LSD $=$ Fisher's protected least significant difference. Means followed by the same letter within a column are not significantly different. 'Log' or 'rank': original means are presented but means separation by LSD was based on logarithmic transformation or Friedman's nonparametric rank test, respectively, because of heterogeneous variances and/or non-normal distribution of residuals. 
Fusarium spp. was similar between treatments on both lots (Table 5). The seed lot in trial 2 was severely infested with Alternaria spp. (96.3\% on nontreated seed) compared with the lot in trial $1(13.3 \%)$. GTG II and GTG I reduced the incidence of Alternaria spp. on this lot to 2.3 and $3.0 \%$, respectively, and Mycostop Mix reduced the incidence of Alternaria spp. to $88.0 \%$ (Table 5).

In the seed lot used in trial 1, Trichoderma spp. were significantly more prevalent on seed treated with GTG II $(99.3 \%)$ and T-22 Planter Box (48.5\%) compared with nontreated seed $(0 \%)$. In the seed lot in trial 2, Trichoderma spp. were detected in $54.0 \%$ of the seed treated with GTG II and $72.8 \%$ of the seed treated with $\mathrm{T}-22$ Planter Box versus 0\% for nontreated seed. These two treatments contained T. harzianum (Table 1). For the second seed lot, the incidence of actinomycetes observed on seed was significantly greater on seed treated with Mycostop Mix $(91.0 \%)$ and Natural II (4.0\%) compared with nontreated seed $(1.8 \%)$. The active ingredients in Mycostop Mix and Natural II are actinomycetes (Table 1).

Germination assays of treated seed. After 7 days, only seed treated with GTG I and GTG II had significantly greater germination than the nontreated seed in trial 1 (Table 6). In contrast, Natural II and Natural $\mathrm{X}$ significantly reduced germination. Results were similar in trial 2 . In the second trial, GTG I was the only treatment that resulted in significantly greater germination relative to that of nontreated seed after 14 days. After 21 days, seed treated with GTG I, GTG II, and Mycostop Mix had significantly greater germination compared with nontreated seed (Table 6). The incidences of abnormal germination, rotten seed, and nongerminated seeds were similar among treatments for each seed lot (data not shown).

\section{DISCUSSION}

The inoculum density of $P$. ultimum provided a consistent level of disease pressure and resulted in a similar incidence of pre- and postemergence damping-off that differentiated efficacy of the treatments under the conditions of the greenhouse trials. In both trials, drench treatments with Micro 108, Prestop, SoilGard 12G, and T22 Planter Box increased damping-off compared with other treatments, as did the compost tea drench in one trial. The drench treatments may have exacerbated disease because of the additional liquid added to the potting medium compared with seed treatments since $P$. ultimum thrives under wet soil conditions (18). However, the compost tea used in this study significantly suppressed damping-off caused by $P$. ultimum in another study (37). For P. ultimum, two experimental seed treatments, GTG I and GTG II, provided consistent control of damping-off equivalent to that provided by the fungicide Apron XL LS (mefenoxam), while Natural II, Natural X, and Subtilex seed treatments suppressed damping-off in only one of the two trials. Although T. harzianum is one of the active ingredients in GTG II and was active against Pythium damping-off of cotton (20), T. harzianum was not in GTG I, which showed a similar level of control of P. ultimum as GTG II. This suggests the organic disinfectant in each of these products was the primary ingredient that reduced damping-off from $P$. ultimum. A second treatment evaluated in this study with the same T-22 strain of $T$. harzianum (T-22 Planter Box) did not significantly reduce damping-off caused by $P$. ultimum. Other biological control agents have been shown to effectively reduce damping-off caused by Pythium spp. on a variety of crops, including Enterobacter cloaceae, Pantoea agglomerans, Pseudomonas fluorescens, and Rhizobium leguminosarum bv. viceae $(21,33,43)$. Although the labels for Mycostop Mix, Prestop, SoilGard 12G, and T-22 Planter Box state efficacy of the products for suppressing damping-off by Pythium spp., these products were not effective against $P$. ultimum under the conditions of this trial.

Preemergence damping-off caused by $R$. solani was generally more prevalent than postemergence damping-off. It is well known that $R$. solani can rapidly increase inoculum and can infect seeds before and during germination, often causing low emergence $(3,31)$ as observed in the greenhouse trials in this study. An inoculum density of 50,000 CFU/g resulted in $75 \%$ damping-off, while 25,000 CFU/g resulted in inadequate disease pressure. Quantifying Rhizoctonia spp. using soil dilution plating methods can be difficult (34), and inoculum density of the $R$. solani soil/oatmeal inoculum in this study was variable among batches of inoculum (data not shown). Nonetheless, in trial 1 seed

Table 5. Results of a freeze-blotter seed health assay of seed with treatments evaluated for management of damping-off or seedling blight in organic spinach ${ }^{\mathrm{x}}$

\begin{tabular}{|c|c|c|c|c|c|c|c|c|}
\hline \multirow[b]{3}{*}{ Seed treatment ${ }^{y}$} & \multicolumn{8}{|c|}{ \% Seed infected or infested (14 days after plating) } \\
\hline & \multicolumn{4}{|c|}{ Trial 1} & \multicolumn{4}{|c|}{ Trial 2} \\
\hline & $\begin{array}{l}\text { Stemphylium } \\
\text { botryosum }\end{array}$ & $\begin{array}{l}\text { Verticillium } \\
\text { spp. }\end{array}$ & $\begin{array}{l}\text { Fusarium } \\
\text { spp. }\end{array}$ & $\begin{array}{l}\text { Alternaria } \\
\text { spp. }\end{array}$ & $\begin{array}{l}\text { Stemphylium } \\
\text { botryosum }\end{array}$ & $\begin{array}{l}\text { Verticillium } \\
\text { spp. }\end{array}$ & $\begin{array}{l}\text { Fusarium } \\
\text { spp. }\end{array}$ & $\begin{array}{l}\text { Alternaria } \\
\text { spp. }\end{array}$ \\
\hline Nontreated & $4.00 \mathrm{bcd}$ & $49.75 \mathrm{a}$ & $2.25 \mathrm{abcd}$ & $13.25 \mathrm{ab}$ & $5.50 \mathrm{c}$ & $1.25 \mathrm{bc}$ & $0.00 \mathrm{a}$ & $96.25 \mathrm{ab}$ \\
\hline GTG I & $17.50 \mathrm{a}$ & $10.50 \mathrm{c}$ & $1.75 \mathrm{abcd}$ & $5.00 \mathrm{de}$ & $11.25 \mathrm{a}$ & $10.25 \mathrm{a}$ & $0.00 \mathrm{a}$ & $3.00 \mathrm{~d}$ \\
\hline GTG II & 3.50 bcde & $0.75 \mathrm{e}$ & $0.25 \mathrm{~cd}$ & $0.50 \mathrm{f}$ & $9.50 \mathrm{ab}$ & $8.50 \mathrm{ab}$ & $0.75 \mathrm{a}$ & $2.25 \mathrm{~d}$ \\
\hline $\begin{array}{l}\text { Kodiak Concentrate } \\
\text { Biological Fungicide }\end{array}$ & $3.50 \mathrm{bcde}$ & $48.50 \mathrm{a}$ & $1.75 \mathrm{abc}$ & $10.25 \mathrm{ab}$ & $5.00 \mathrm{c}$ & $0.75 \mathrm{~cd}$ & $0.00 \mathrm{a}$ & $98.00 \mathrm{ab}$ \\
\hline Micro 108 Seed Inoculant & $4.50 \mathrm{bc}$ & $48.75 \mathrm{a}$ & $4.75 \mathrm{a}$ & $14.00 \mathrm{a}$ & $4.25 \mathrm{c}$ & $1.00 \mathrm{~cd}$ & $0.00 \mathrm{a}$ & $98.50 \mathrm{a}$ \\
\hline Mycostop Mix Biofungicide & $0.50 \mathrm{f}$ & $13.00 \mathrm{c}$ & $3.50 \mathrm{ab}$ & $2.00 \mathrm{ef}$ & $0.50 \mathrm{~d}$ & $0.75 \mathrm{~cd}$ & $0.00 \mathrm{a}$ & $88.00 \mathrm{c}$ \\
\hline Natural II & $0.50 \mathrm{f}$ & $4.75 \mathrm{~d}$ & $1.25 \mathrm{abcd}$ & $0.25 \mathrm{f}$ & $6.25 \mathrm{bc}$ & $1.00 \mathrm{~cd}$ & $0.00 \mathrm{a}$ & $97.75 \mathrm{ab}$ \\
\hline Natural X & $1.75 \mathrm{def}$ & $20.25 \mathrm{~b}$ & $0.75 \mathrm{bcd}$ & $1.00 \mathrm{f}$ & $3.75 \mathrm{~cd}$ & $0.50 \mathrm{~cd}$ & $0.00 \mathrm{a}$ & $97.25 \mathrm{ab}$ \\
\hline PGPR Galaxy & $4.50 \mathrm{bc}$ & $45.75 \mathrm{a}$ & $2.25 \mathrm{ab}$ & $9.25 \mathrm{bc}$ & $4.25 \mathrm{c}$ & $0.75 \mathrm{~cd}$ & $0.00 \mathrm{a}$ & $98.00 \mathrm{ab}$ \\
\hline Subtilex Biological Fungicide & $2.00 \mathrm{cdef}$ & $45.25 \mathrm{a}$ & $2.75 \mathrm{ab}$ & $7.25 \mathrm{~cd}$ & $3.25 \mathrm{~cd}$ & $0.75 \mathrm{~cd}$ & $0.25 \mathrm{a}$ & $97.50 \mathrm{ab}$ \\
\hline $\begin{array}{l}\text { T-22 Planter Box Biological } \\
\text { Fungicide }\end{array}$ & $1.75 \mathrm{def}$ & $41.50 \mathrm{a}$ & $3.00 \mathrm{a}$ & $10.50 \mathrm{ab}$ & $5.25 \mathrm{c}$ & $0.00 \mathrm{~d}$ & $0.50 \mathrm{a}$ & $96.00 \mathrm{~b}$ \\
\hline $\begin{array}{l}\text { Yield Shield Concentrate } \\
\text { Biological Fungicide }\end{array}$ & 3.00 bcde & $49.25 \mathrm{a}$ & $1.25 \mathrm{abcd}$ & $11.75 \mathrm{ab}$ & $3.00 \mathrm{~cd}$ & $1.00 \mathrm{~cd}$ & $0.00 \mathrm{a}$ & $98.50 \mathrm{ab}$ \\
\hline Apron XL LS & $1.50 \mathrm{ef}$ & $40.75 \mathrm{a}$ & $2.00 \mathrm{ab}$ & $3.75 \mathrm{def}$ & $3.25 \mathrm{~cd}$ & $0.50 \mathrm{~cd}$ & $0.00 \mathrm{a}$ & $98.25 \mathrm{ab}$ \\
\hline Mertect 340F & $6.00 \mathrm{~b}$ & $0.75 \mathrm{e}$ & $0.00 \mathrm{~d}$ & $11.5 \mathrm{ab}$ & $4.50 \mathrm{c}$ & $0.00 \mathrm{~d}$ & $0.00 \mathrm{a}$ & $97.25 \mathrm{ab}$ \\
\hline $\operatorname{LSD}(P<0.05)^{\mathrm{z}}$ & $\log$ & $\log$ & Rank & Rank & 3.567 & Rank & NS & Arcsin \\
\hline
\end{tabular}

${ }^{x}$ Four replications of 100 seeds/treatment assayed as described by du Toit et al. (11). A different commercial seed lot of the hybrid Lazio was evaluated in each trial.

y Not all products were EPA registered or reviewed for compliance with the USDA National Organic Program (NOP) or the Organic Materials Review Institute (OMRI) in 2007. Apron XL LS (mefenoxam) and Mertect 340F (thiabendazole) were conventional fungicide seed treatments for control of Pythium spp. and Fusarium spp., respectively. Refer to Table 1 for details of the seed treatments.

${ }^{\text {z }}$ LSD = Fisher's protected least significant difference. Means followed by the same letter within a column are not significantly different. 'Log', 'arcsin', and 'rank': original means are presented but means separation is based on transformation (logarithmic or arcsin square root transformation) or Friedman's nonparametric rank test, respectively, because of heterogeneous variances and/or non-normal distribution of residuals. NS $=$ not significantly different at $P<0.05$ (41). 
treatment with GTG I and Natural II resulted in emergence similar to the Terraclor fungicide drench. The active ingredients of GTG I and Natural II are an organic disinfectant and an actinomycete, respectively. Other biological control agents, including $P$. aeruginosa and $P$. fluorescens, $P$. putida, T. harzianum, Gliocladium spp., and Bacillus amyloliquefaciens, have been shown to effectively reduce damping-off caused by Rhizoctonia spp. on a variety of crops $(4,7,15,17,28,29,39)$. However, treatments evaluated in this study with these active ingredients (GTG II, PGPR Galaxy, PreStop, SoilGard 12G, and T-22 Planter Box) did not reduce damping-off by $R$. solani even though the labels for Kodiak, Mycostop Mix, Prestop, SoilGard 12G, Subtilex, T-22 Planter Box, and Yield Shield state efficacy at suppressing Rhizoctonia spp. Marshall (29) demonstrated that seed treatment with $T$. harzianum resulted in a greater reduction in disease caused by $R$. solani at a soil $\mathrm{pH}$ of 3.5 versus 5.6. This suggests that products evaluated in this study that contained Trichoderma spp. may have been limited in efficacy by the $\mathrm{pH}$ of the potting medium, which ranged from 6.40 to 6.46 .

Fusarium wilts are generally more severe in warm soils (6). For the inoculum density trials with $F$. oxysporum f. sp. spinaciae, postemergence wilt was the predominant symptom. In trial $1,10,000$ CFU/g achieved approximately $50 \%$ wilt for nontreated seed. However, in trial 2 this concentration resulted in $30 \%$ wilt from nontreated seed, which may have limited the ability to differentiate among seed and drench treatments. Additionally, these trials were carried out for $>40$ days, which may have impacted efficacy of the treat- ments, as many seed treatments have efficacy against specific pathogens for a limited duration after planting (16).

In this study, only PreStop Biofungicide consistently reduced the incidence of postemergence wilt caused by $F$. oxysporum f. sp. spinaciae, although flats drenched with this product had significantly more preemergence damping-off than flats planted with nontreated seed. The compost tea drench and Yield Shield seed treatment each suppressed wilt significantly in one of the two trials. Other biological control agents have been shown to effectively reduce wilt caused by Fusarium spp., including $P$. fluorescens, $P$. putida, Glomus intraradices, G. mosseae, E. cloaceae, R. leguminosarum, Trichoderma spp., G. virens, Burkholderia cepacia, and nonpathogenic Fusarium spp. $(2,12,13,26,27,36)$. However, in this study, treatments with the active ingredients listed in those studies (GTG II, PGPR Galaxy, SoilGard 12G, and T-22 Planter Box) did not reduce wilt caused by $F$. oxysporum f. sp. spinaciae. In each trial, total wilt for the Mertect 340F fungicide seed treatment plots also was similar to that of nontreated seed, indicating that this fungicide seed treatment was not effective for management of Fusarium wilt under the conditions of these trials.

Seed treatments can protect against seedborne as well as soilborne pathogens $(1,32,42)$. Seed health assays in this study indicated differences in the incidence of some seedborne necrotrophic fungi, particularly Verticillium spp. and Alternaria spp., in the two commercial seed lots. One of the seed lots was highly infested with Alternaria spp., which may have suppressed development of other fungi on the seed (Verticillium spp. and S. botryosum). This was apparent for seed treated with GTG I and GTG II, which had significantly less seed with Alternaria spp. but greater amounts of Verticillium spp. and $S$. botryosum. Stemphylium and Verticillium infections of spinach seed can be deep in the pericarp and even in the embryo (19), which might explain why the organic disinfectant in GTG I and GTG II did not eliminate these fungi from the seed. A greater proportion of seed were colonized by actinomycetes for the Mycostop Mix and Natural II seed treatments compared with any other treatment. Similarly, Trichoderma spp. were more prevalent on seed treated with GTG II and T-22 Planter Box, demonstrating the presence of the biological control agents contained in these products.

Seed treated with GTG I and GTG II had the earliest germination in all trials as well as the germination assays. Early germination and emergence could reduce the duration of susceptibility of spinach seedlings to infection by $P$. ultimum and $R$. solani, since these pathogens do not cause losses in more mature plants (8). Seed treated with Natural II had delayed germination, consistent with previous spinach seed trials with this product (9). GTG I, GTG II, and Mycostop Mix increased seed germination and reduced the incidence of seedborne Alternaria spp., which can cause seed rot on various crops (1), on one of the spinach seed lots.

Inconsistency in performance was observed in this study for many of the seed and drench treatments evaluated. This could be attributed to a number of factors, such as differences in incidence of seedborne fungi that may have affected efficacy

Table 6. Results of a germination assay of spinach seed with treatments evaluated for management of damping-off and seedling blight in organic spinach ${ }^{\mathrm{x}}$

\begin{tabular}{|c|c|c|c|c|c|c|c|}
\hline \multirow[b]{3}{*}{ Seed treatment $\mathbf{t}^{\mathrm{y}}$} & \multicolumn{7}{|c|}{$\%$ Seed germination } \\
\hline & \multicolumn{3}{|c|}{ Trial 1} & \multicolumn{4}{|c|}{ Trial 2} \\
\hline & 7 days & 14 days & 21 days & 5 days & 7 days & 14 days & 21 days \\
\hline Nontreated & $50.25 \mathrm{~cd}$ & $88.75 \mathrm{a}$ & $90.25 \mathrm{a}$ & $16.00 \mathrm{cde}$ & $80.50 \mathrm{abc}$ & 88.50 bcde & $88.50 \mathrm{cdef}$ \\
\hline GTG I & $70.00 \mathrm{a}$ & $92.00 \mathrm{a}$ & $92.50 \mathrm{a}$ & $38.00 \mathrm{a}$ & $78.00 \mathrm{~cd}$ & $92.50 \mathrm{a}$ & $93.25 \mathrm{a}$ \\
\hline GTG II & $64.50 \mathrm{ab}$ & $89.50 \mathrm{a}$ & $91.00 \mathrm{a}$ & $29.25 \mathrm{~b}$ & $76.25 \mathrm{~cd}$ & $90.75 \mathrm{abc}$ & $92.75 \mathrm{a}$ \\
\hline Kodiak Concentrate Biological Fungicide & $52.50 \mathrm{~cd}$ & $89.50 \mathrm{a}$ & $90.50 \mathrm{a}$ & $19.00 \mathrm{~cd}$ & $78.00 \mathrm{~cd}$ & 85.25 ef & $85.50 \mathrm{fg}$ \\
\hline Micro 108 Seed Inoculant & $51.75 \mathrm{~cd}$ & $88.25 \mathrm{a}$ & $88.75 \mathrm{a}$ & $18.50 \mathrm{~cd}$ & $82.75 \mathrm{abc}$ & 88.75 abcde & 88.75 bcdef \\
\hline Mycostop Mix Biofungicide & $47.00 \mathrm{de}$ & $88.00 \mathrm{a}$ & $89.00 \mathrm{a}$ & $21.75 \mathrm{bc}$ & $85.25 \mathrm{ab}$ & $92.25 \mathrm{ab}$ & $92.50 \mathrm{ab}$ \\
\hline Natural II & $34.75 \mathrm{f}$ & $88.75 \mathrm{a}$ & $90.75 \mathrm{a}$ & $10.50 \mathrm{e}$ & $80.50 \mathrm{abc}$ & $91.25 \mathrm{abc}$ & $91.50 \mathrm{abcd}$ \\
\hline Natural X & 40.50 ef & $89.00 \mathrm{a}$ & $90.25 \mathrm{a}$ & $16.75 \mathrm{cde}$ & $79.25 \mathrm{bcd}$ & $90.50 \mathrm{abc}$ & 90.50 abcde \\
\hline PGPR Galaxy & $53.75 \mathrm{~cd}$ & $85.75 \mathrm{a}$ & $87.25 \mathrm{a}$ & 17.50 cde & $78.50 \mathrm{~cd}$ & $86.50 \mathrm{def}$ & 87.00 efg \\
\hline Subtilex Biological Fungicide & $57.00 \mathrm{bc}$ & $90.00 \mathrm{a}$ & $91.00 \mathrm{a}$ & $17.25 \mathrm{cde}$ & $81.00 \mathrm{abc}$ & $88.00 \mathrm{cdef}$ & $88.50 \mathrm{cdef}$ \\
\hline T-22 Planter Box Biological Fungicide & $55.00 \mathrm{~cd}$ & $89.25 \mathrm{a}$ & $90.25 \mathrm{a}$ & $12.25 \mathrm{de}$ & $86.50 \mathrm{a}$ & $92.25 \mathrm{ab}$ & $92.25 \mathrm{abc}$ \\
\hline Yield Shield Concentrate Biological Fungicide & $49.50 \mathrm{~cd}$ & $89.50 \mathrm{a}$ & $90.75 \mathrm{a}$ & 17.25 cde & $81.50 \mathrm{abc}$ & 90.00 abcd & 90.00 abcde \\
\hline Apron XL LS & $55.75 \mathrm{c}$ & $90.25 \mathrm{a}$ & $91.25 \mathrm{a}$ & $15.25 \mathrm{cde}$ & $73.75 \mathrm{~d}$ & $84.25 \mathrm{f}$ & $84.25 \mathrm{~g}$ \\
\hline Mertect 340F & $42.50 \mathrm{~cd}$ & $89.50 \mathrm{a}$ & $91.50 \mathrm{a}$ & $16.25 \mathrm{cde}$ & $82.25 \mathrm{abc}$ & 87.75 cdef & $87.75 \mathrm{defg}$ \\
\hline $\operatorname{LSD}(P<0.05)^{\mathrm{z}}$ & 8.311 & NS & NS & 7.521 & 6.737 & 3.940 & 3.771 \\
\hline
\end{tabular}

$\mathrm{x}$ The Association of Official Seed Analysts (AOSA) blotter germination assay (44) for four replications of 100 seeds/treatment. A different commercial seed lot of the hybrid Lazio was evaluated in each trial. The percent abnormally germinated seed, rotten seed, and nongerminated seed were recorded at 21 days, with no significant differences detected among treatments for these variables based on analyses of variance (data not shown).

y Not all products were EPA registered or reviewed for compliance with the USDA National Organic Program (NOP) or the Organic Materials Review Institute (OMRI) in 2007. Apron XL LS (mefenoxam) and Mertect 340F (thiabendazole) were included as conventional fungicide seed treatments for control of Pythium spp. and Fusarium spp., respectively. Refer to Table 1 for details of each treatment.

${ }^{\mathrm{z}}$ LSD $=$ Fisher's protected least significant difference. Means followed by the same letter within a column are not significantly different. NS $=$ not significantly different at $P<0.05(41)$. 
of some treatments. However, the seed lots used in these trials were commercially available. The products also need to be evaluated under diverse field conditions to assess potential efficacy and consistency in performance. Of the 14 organic seed and drench treatments evaluated, GTG I and GTG II were the most consistent and effective at reducing damage to spinach from $P$. ultimum and $R$. solani, but not from $F$. oxysporum f. sp. spinaciae. None of the treatments provided complete protection against all three pathogens. Specific treatments may be more effective under certain conditions, as the consistency in performance of seed treatments can be affected by crop species, product formulation, seedborne or soilborne pathogens, and soil conditions (42). It is important to assess each treatment on specific crop species of interest under the diversity of production conditions in which the products might be used. Furthermore, the results highlight the need for potential users of such organic products to obtain accurate diagnoses of the specific damping-off pathogens present in fields in which the seed or drench treatments are to be used, in order to select the appropriate product(s) with highest efficacy against the particular pathogen(s) of concern. Research is also needed to evaluate combinations of seed and/or drench treatments against damping-off pathogens, individually and in combinations, in a diversity of field conditions.

\section{ACKNOWLEDGMENTS}

The authors gratefully acknowledge the financial support for this project from the Organic Program of the WSU Center for Sustaining Agriculture and Natural Resources and the Alfred Christianson Endowment. In addition, excellent technical support was provided by L. Brissey, K. Brooks, M. Derie, B. Holmes, and J. Riske; with valuable mentoring from D. Inglis and F. Dugan on J. Cummings' M.S. thesis committee. The project was supported by the WSU Department of Plant Pathology (PPNS no. 0522) in the College of Agricultural, Human, and Natural Resource Sciences Agricultural Research Center for CRIS Project no. WNP00595. The authors thank D. Gent and L. Porter for internal reviews of the manuscript.

\section{LITERATURE CITED}

1. Agarwal, V. K., and Sinclair, J. B. 1997. Principles of Seed Pathology, 2nd Ed. CRC Press, Inc., Boca Raton, FL.

2. Akkopru, A., and Demir, S. 2005. Biological control of Fusarium wilt in tomato caused by Fusarium oxysporum f. sp. lycopersici by AMF Glomus intraradices and some rhizobacteria. J. Phytopathol. 153:544-550.

3. Baker, K. F. 1970. Types of Rhizoctonia diseases and their occurrence. Pages 125-148 in: Rhizoctonia solani, Biology and Pathology. University of California Press, Berkeley, CA.

4. Baker, R., and Paulitz, T. C. 1996. Theoretical basis for microbial interaction leading to biological control of soilborne plant pathogens. Pages 50-79 in: Principles and Practice of Managing Soilborne Plant Pathogens. R. Hall, ed. American Phytopathological Society, St. Paul, MN.

5. Bassi, A., Jr., and Goode, M. J. 1978. Fusarium oxysporum $\mathrm{f}$. sp. spinaciae seedborne in spinach. Plant Dis. Rep. 62:203-205.
6. Bruehl, G. W. 1987. Soilborne Plant Pathogens. Macmillan Publishing Co., New York, NY.

7. Chung, W. C., Huang, J. W., and Huang, H. C. 2005. Formulation of a soil biofungicide for control of damping-off of Chinese cabbage (Brassica chinensis) caused by Rhizoctonia solani. Biol. Control 32:287-294.

8. Correll, J. C., Morelock, T. E., Black, M. C., Koike, S. T., Brandenberger, L. P., and Dainello, F. J. 1994. Economically important diseases of spinach. Plant Dis. 78:653-660.

9. du Toit, L. J., Derie, M. L., and Brissey, L. M. 2007. Evaluation of fungicides for control of seedborne Stemphylium botryosum on spinach. Plant Dis. Manage. Rep. 1:ST003.

10. du Toit, L. J., Derie, M. L., Brissey, L. M., Cummings, J. A. 2007. Evaluation of limestone amendments for control of Fusarium wilt in a spinach seed crop. Plant Dis. Manage. Rep. 1:V091

11. du Toit, L. J., Derie, M. L., and HernandezPerez, P. 2005. Verticillium wilt in spinach seed production. Plant Dis. 89:4-11.

12. Fravel, D., Olivain, C., and Alabouvette, C. 2003. Fusarium oxysporum and its biocontrol. New Phytol. 157:493-502.

13. Hassan Dar, G., Zargar, M. Y., and Beigh, G. M. 1997. Biocontrol of Fusarium root rot in the common bean (Phaseolus vulgaris L.) by using symbiotic Glomus mossea and Rhizobium leguminosarum. Microb. Ecol. 34:7480 .

14. Groot, S., van der Wolf, J. M., Jalink, H., Langerak, C. J., and van den Bulk, R. W. 2004. Challenges for the production of high quality organic seeds. Seed Testing International ISTA News Bull. No. 127:12-15.

15. Grosch, R., Franziska, F., Lottmann, J., Kofoet, A., and Berg, G. 2005. Effectiveness of three antagonistic bacterial isolates to control Rhizoctonia solani Kuhn on lettuce and potato. Can. J. Microbiol. 51:345-353.

16. Harman, G. E. 1991. Seed treatments for biological control of plant disease. Crop Prot. 10:166-171.

17. Harris, A. R., and Adkins, P. G. 1999. Versatility of fungal and bacterial isolates for biological control of damping-off disease caused by Rhizoctonia solani and Pythium species. Biol. Control 15:10-18.

18. Hendrix, F. F., and Campbell, W. A. 1973. Pythiums as plant pathogens. Annu. Rev. Phytopathol. 11:77-98.

19. Hernandez-Perez, P., and du Toit, L. J. 2006. Seedborne Cladosporium variabile and Stemphylium botryosum in spinach. Plant Dis. 90:137-145.

20. Howell, C. R. 2007. Effect of seed quality and combination fungicide-Trichoderma spp. seed treatments on pre- and postemergence damping-off in cotton. Phytopathology 97:66-71.

21. Huang, H. C., and Erickson, R. S. 2007. Effect of seed treatment with Rhizobium leguminosarum on Pythium damping-off, seedling height, root nodulation, root biomass, shoot biomass, and seed yield of pea and lentil. J. Phytopathol. 155:31-37.

22. Irish, B. M., Correll, J. C., Koike, S. T., and Morelock, T. E. 2007. Three new races of the spinach downy mildew pathogen identified by a modified set of spinach differentials. Plant Dis. 91:1392-1396.

23. Kerr, A. 1963. The root rot Fusarium wilt complex of pea. Aust. J. Biol. Sci. 16:55-69.

24. Koenig, R. L., and Baker, B. 2002. U.S. National Organic Program Standards: Implications for researchers. APSnet http://www. apsnet.org/online/feature/organic/.

25. Komada, H. 1975. Development of a selective medium for quantitative isolation of Fusarium oxysporum from natural soil. Rev. Plant Prot. Res. 8:114-125.

26. Larkin, R. P., and Fravel, D. R. 1998. Efficacy of various fungal and bacterial biocontrol organisms for control of Fusarium wilt of tomato. Plant Dis. 82:1022-1028.

27. Leeman, M., van Pelt, J. A., Hendrickx, M. J., Scheffer, R. J., Bakker, P. A. H. M., and Schippers, B. 1995. Biocontrol of Fusarium wilt of radish in commercial greenhouse trials by seed treatment with Pseudomonas fluorescens WCS374. Phytopathology 85:1301-1305.

28. Lewis, J. A., and Papavizas, G. C. 1985. Effect of mycelial preparations of Trichoderma and Gliocladium on populations of Rhizoctonia solani and the incidence of damping-off. Phytopathology 75:812-817.

29. Marshall, D. S. 1982. Effect of Trichoderma harzianum seed treatment and Rhizoctonia solani inoculum concentration on damping-off of snap bean in acidic soils. Plant Dis. 66:788789.

30. Mircetich, S. M., and Kraft, J. M. 1973. Efficiency of various selective media in determining Pythium populations in soil. Mycopathol Mycol. Appl. 50:151-161.

31. Mitchell, J. E. 1979. The dynamics of the inoculum potential of populations of soil-borne plant pathogens in the soil ecosystem. Pages 320 in: Soil-borne Plant Pathogens. B. Schippers and W. Gams, eds. Academic Press, New York.

32. Neergaard, P. 1977. Seed Pathology. John Wiley and Sons, Inc., New York, NY.

33. Nelson, E. B. 1988. Biological control of Pythium seed rot and preemergence dampingoff of cotton with Enterobacter cloacae and Erwinia herbicola applied as seed treatments. Plant Dis. 72:140-142.

34. Paulitz, T. C., and Schroeder, K. L. 2005. A new method for the quantification of Rhizoctonia solani and $R$. oryzae from soil. Plant Dis. 89:767-772.

35. Peever, T. L., Canihos, Y., Olsen, L., Ibanez, A., Liu, Y. C., and Timmer, L. W. 1999. Population genetic structure and host specificity of Alternaria spp. causing brown spot of Minneola tangelo and rough lemon in Florida. Phytopathology 89:851-860.

36. Raaijmakers, J. M., Leeman, M., van Oorschot, M. M. P., van der Sluis, I., Schippers, B., and Bakker, P. A. H. M. 1995. Doseresponse relationships in biological control of Fusarium wilt of radish by Pseudomonas spp. Phytopathology 85:1075-1081.

37. Scheuerell, S., and Mahaffee, W. 2004. Compost tea as a container medium drench for suppressing seedling damping-off caused by $P y$ thium ultimum. Phytopathology 94:1156-1163.

38. Shaner, G., and Finney, R. E. 1977. The effect of nitrogen fertilization on the expression of slow-mildewing resistance in Knox wheat Phytopathology 67:1051-1056.

39. Siddiqui, I. A., and Shaukat, S. S. 2002. Resistance against the damping-off fungus Rhizoctonia solani systemically induced by the plantgrowth-promoting rhizobacteria Pseudomonas aeruginosa (IE-6S+) and $P$. fluorescens (CHA0). J. Phytopathol. 150:500-506.

40. Sneh, B., Burpee, L., and Ogoshi, A. 1991. Identification of Rhizoctonia Species. American Phytopathological Society, St. Paul, MN

41. Steele, R. G. D., and Torrie, J. H. 1980. Principles and Procedures of Statistics: A Biometrical Approach, 2nd ed. McGraw Hill, New York, NY.

42. Taylor, A. G., and Harman G. E. 1990. Concepts and technologies of selected seed treatments. Annu. Rev. Phytopathol. 28:321-339.

43. Trapero-Casas, A., Kaiser, W. J., and Ingram, D. M. 1990. Control of Pythium seed rot and preemergence damping-off of chickpea in the U.S. Pacific Northwest and Spain. Plant Dis. 74:563-569.

44. Yaklich, R. W. 1985. Germination tests. Pages 30-36 in: Rules for Testing Seeds. Association of Official Seed Analysts. J. Seed Technol. 8:2. 